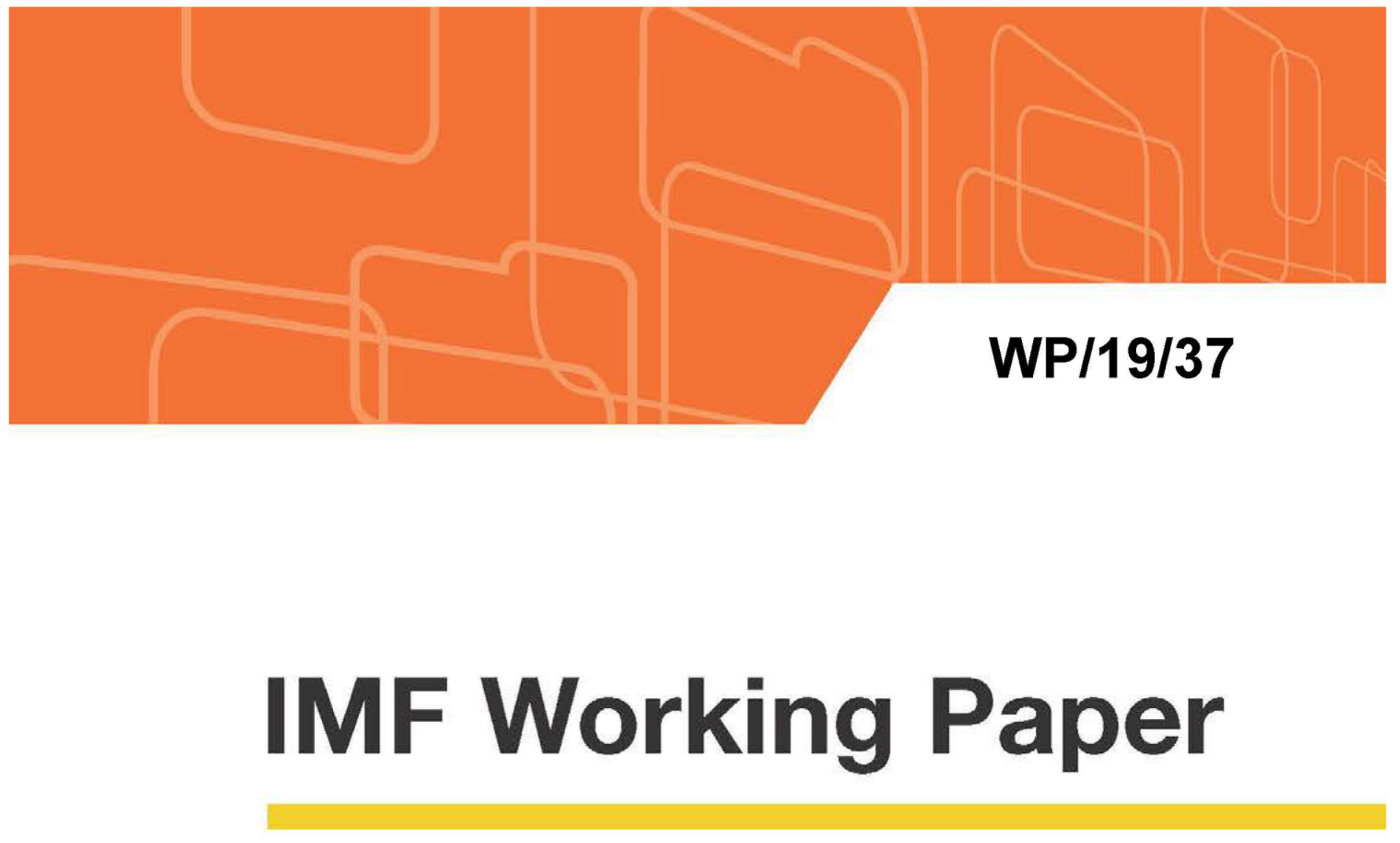

\title{
Debt Build-up in Frontier Low-Income Developing Countries (LIDCs) since 2012: Global or Country-specific Factors and Way Forward?
}

by Constance de Soyres, Anna Rogantini Picco, and Randa Sab

IMF Working Papers describe research in progress by the author(s) and are published to elicit comments and to encourage debate. The views expressed in IMF Working Papers are those of the author(s) and do not necessarily represent the views of the IMF, its Executive Board, or IMF management. 


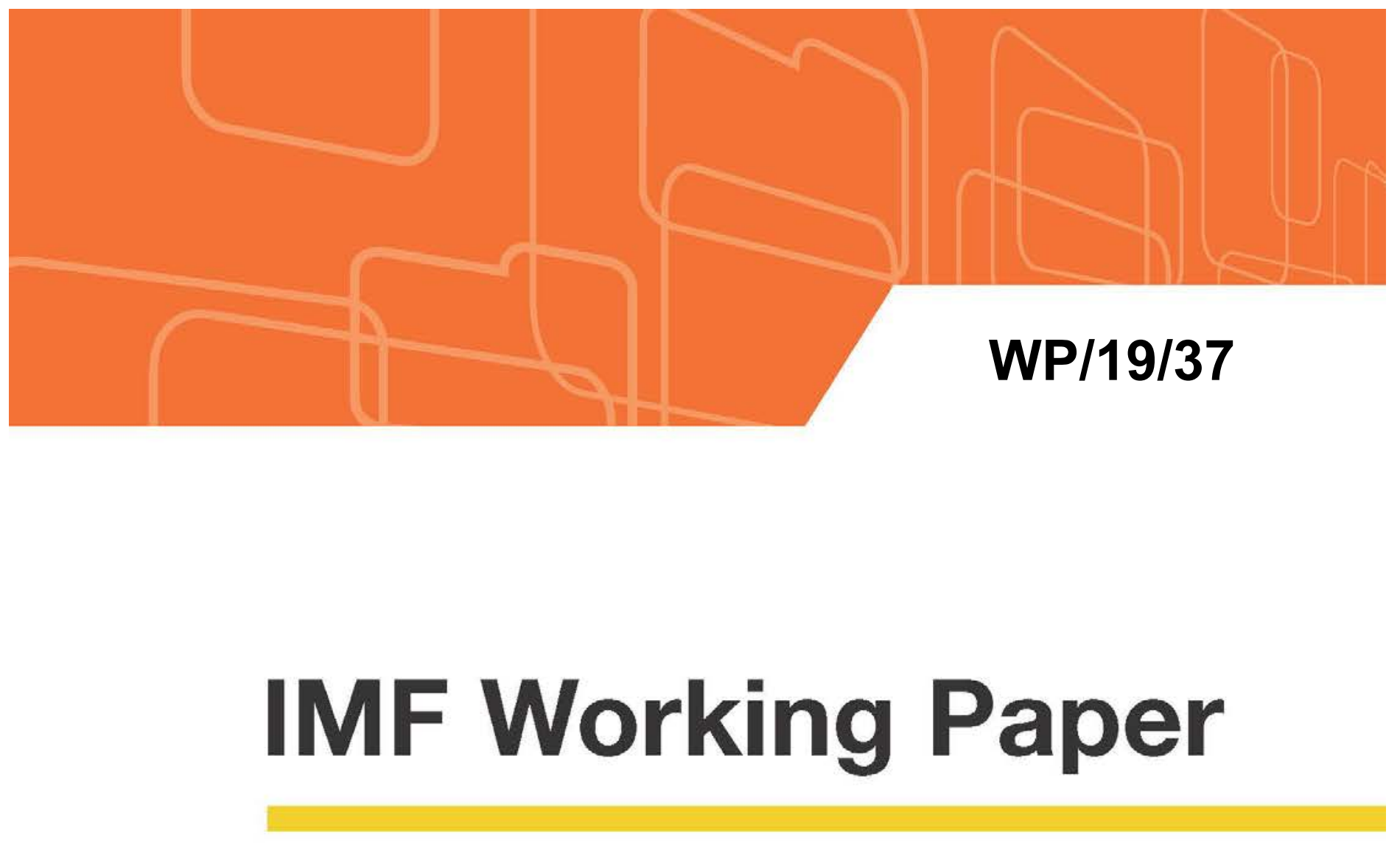

\section{Debt Build-up in Frontier Low-Income Developing Countries (LIDCs) since 2012: Global or Country-specific Factors and Way Forward?}

by Constance de Soyres, Anna Rogantini Picco, and Randa Sab

IMF Working Papers describe research in progress by the author(s) and are published to elicit comments and to encourage debate. The views expressed in IMF Working Papers are those of the author(s) and do not necessarily represent the views of the IMF, its Executive Board, or IMF management. 
(C) 2019 International Monetary Fund

WP/19/37

\title{
IMF Working Paper
}

Finance Department

\section{Debt Build-up in Frontier Low-Income Developing Countries (LIDCs) since 2012: Global or Country-specific Factors and Way Forward?}

Prepared by Constance de Soyres, Anna Rogantini Picco, and Randa Sab ${ }^{2}$

Authorized for distribution by Charleen Adam Gust

February 2019

IMF Working Papers describe research in progress by the author(s) and are published to elicit comments and to encourage debate. The views expressed in IMF Working Papers are those of the author(s) and do not necessarily represent the views of the IMF, its Executive Board, or IMF management.

\begin{abstract}
This paper focuses on the debt build-up that frontier low-income developing countries (LIDCs) have faced since 2012. First, it documents a 20-percentage point increase in the external and government debt-to-GDP ratios, a composition shift toward higher nonconcessional debt, and a rise in interest rate payments. Second, using panel regressions, it shows that while both global and country-specific factors are correlated with debt-to-GDP ratios over 1998-2016, global factors dominate for the period 2012-16. Third, through a small open-economy model, it shows that the projected tightening in global financial conditions would reduce debt-to-GDP ratios by less than the increase associated with the expected rise in investment.
\end{abstract}

JEL Classification Numbers: E6, F3, H6

Keywords: Debt build-up, Frontier LIDCs, global and country-specific factors

\footnotetext{
${ }^{1}$ Authors’ email addresses: Cdesoyres@imf.org, Anna.Rogantini@eui.eu, Rsab@imf.org.

${ }^{2}$ Anna Rogantini Picco was a summer intern in the Finance Department of the IMF when this paper was prepared. She is a $\mathrm{PhD}$ candidate at the European University Institute, Florence, IT. The authors would like to thank Gilda Fernandez and Christian Mumssen for their invaluable feedback since the onset of the project. The authors are also grateful to Jean Acheson, Olusegun Akanbi, Anil Ari, Claudia Berg, Matteo Gatti, Chris Geiregat, Charleen Adam Gust, Andrew Kanyegirire, Suhaib Kebhaj, Eteri Kvintradze, Lam Nguyen, Mwanza Nkusu, Joonseok Oh, Erica Tsounta, Olaf Unteroberdoerster, and participants at the Finance Department's seminar on August 15, 2018 for helpful comments and suggestions, and Amy Miranda and Shanika Jayakody for administrative support.
} 
TABLE OF CONTENTS

Abstract

I. Introduction

II. Literature Review __ 6

III. The Recent Debt Build-up in Frontier LIDCs: Stylized Facts___ 7

IV. Global or Country-Specific Factors? __ 14

V. Policy Implications _

VI. Conclusions _ 27

References __ 29

\section{FIGURES}

1. Frontier LIDCs: Debt-to-GDP Ratios__ $\underline{9}$

2. Frontier LIDCs: External Debt Characteristics

3. Frontier LIDCs: Interest Rate Burden

4. Global Environment

5. Frontier LIDCs: Financial Cost and Financing Inflows __ 12

6. Frontier LIDCs: External Position

7. Frontier LIDCs: Fiscal Position

8. Frontier LIDCs: Fiscal Trends

9. Interest Rate Tightening _

10. Increase in Marginal Efficiency of Investment___ 26

\section{TABLES}

1. Sample of Countries

2. Overview of Main Variables of Interest

3. Frontier LIDCs: Debt Determinants: 1998-2016__ 18

4. Frontier LIDCs: Debt Determinants: 1998-2011

5. Frontier LIDCs: Debt Determinants: 2012-16

6. Frontier LIDCs: External Debt Determinants: 2012-16 __ 21

7. Calibration
APPENDICES
1. Literature Review of the Main Empirical Studies on Debt Determinants
2. Data Sources and Description
3. Debt-to-GDP Ratios: Descriptive Statistics $\underline{38}$
4. Additional Impulse Response Functions to Shocks

$\underline{39}$


APPENDIX FIGURES

A3.1 Debt-to-GDP Ratios: Median and Interquartile Range $\underline{38}$

A4.1. Interest Rate Tightening

A4.2 Increase in Marginal Efficiency of Investment $\underline{40}$

APPENDIX TABLE

A3.1 Debt-to-GDP Ratios: Additional Descriptive Statistics $\underline{38}$ 


\section{INTRODUCTION}

The recent increase in debt-to-GDP ratios across low-income developing countries (LIDCs) has raised new debt sustainability concerns. Following a substantial fall from the early 2000s to 2011 on the back of robust growth and the Heavily Indebted Poor Country (HIPC) initiative, debt-to-GDP ratios started to increase again, raising concerns about fiscal sustainability, the diversion of scarce budgetary resources to meet debt service obligations, and the heightened risks associated with changes in the borrowing structure. ${ }^{3}$

Against this backdrop, this paper focuses on "frontier" LIDCs, a sub-group of low-income developing countries that have been recently integrated with international markets. ${ }^{4}$ This group is particularly interesting because debt is affected not only by domestic policies and international prices, but also by global financial conditions. More precisely, we study whether the recent debt build-up correlates with global or country-specific factors; and uses the results to simulate how global conditions and policies may affect future debt dynamics.

Using annual data on external and government debt of frontier LIDCs, this paper documents a cross-country average increase in debt-to-GDP ratios of roughly twenty percentage points over the period 2012-17. It further highlights a shift in the debt composition towards more non-concessional debt. It also shows that the interest rate burden faced by frontier LIDCs has increased for both government and external debt due to a rise in both debt volumes and interest rates.

To disentangle whether the debt build-up correlates more with global or country-specific factors, the paper carries out a panel regression analysis over the period 1998-2016. The regressions show that while both global and country-specific factors are correlated with debtto-GDP ratios over the full sample period, global factors become more dominant in the period 2012-16, when debt-to-GDP ratios have steadily risen.

Despite significant efforts made by the IMF to improve data quality and availability for LIDCs, data limitations are still severe. For example, data on debt are only available at an annual frequency, which imposes some limits to our empirical analysis. As an alternative, in the last part of the paper, we set up a stylized small open economy model to draw forwardlooking policy implications. We build a small open economy model where agents can tap the international markets by issuing one period non-contingent bonds on which they pay an

\footnotetext{
${ }^{3}$ See IMF (2018) for a detailed analysis of the recent debt build-up of debt-to-GDP ratios across LIDCs over the past five years, including a breakdown by commodity exporters, diversified exporters, frontier markets, fragile states, regions, and risk of debt distress.

${ }^{4}$ The definition of frontier market economies was proposed in the IMF policy paper "Macroeconomic Developments in LIDCs (2014)". LIDCs are identified as frontier based on the following five criteria: they are one standard deviation below the Emerging Markets average for the following variables: (i) M2 to GDP, (ii) cross border loans to deposit, (iii) stock market capitalization, (iv) portfolio inflows and (v) they have accessed (or have the potential to access) sovereign bond markets. The defined set of countries is updated by this paper using Bloomberg data on bond issuance in sovereign bond markets for 2014-17, using a similar methodology to $\operatorname{IMF}(2017)$.
} 
exogenous interest rate. The paper then simulates a tightening in the global interest rate calibrated to the Federal Open Market Committee's longer-run projections and shows that the debt-to-GDP ratio would drop. It further simulates an increase in investment calibrated to the cross-country average of the World Economic Outlook (WEO) projections of gross capital formation up to 2024 and shows that this would result in an increase of the debt-to-GDP ratio.

A tightening in the global financial markets may lead to a reversal of capital flows away from frontier LIDCs. The ensuing reduction in the supply of external financing to frontier LIDCs would ultimately contribute to dampening the rise in debt-to-GDP ratios. ${ }^{5}$ In turn, an increase in debt-financed investment could lead to a rise in debt-to-GDP ratios. However, the projected tightening in global financial conditions would reduce debt-to-GDP ratios by less than the increase associated with the expected rise in investment.

The rest of the paper is organized as follows. Section II presents a review of the related empirical literature on debt determinants. Section III illustrates stylized facts on debt buildup in frontier LIDCs. Section IV carries out a panel regression analysis aimed at showing which global and country-specific factors are correlated with the debt-to-GDP ratios over the period 1998-2016. Section V builds a small open economy model to run simulations on the dynamics of the debt-to-GDP ratio. Section VI concludes.

\section{LITERATURE REVIEW}

This paper is mostly related to the empirical literature on debt determinants. Appendix 1 reviews the main studies carried out on debt determinants. For each study, the appendix table highlights the authors, the countries and time coverage, the methodology, the dependent and independent variables of the empirical model, and the main results.

Most of the papers examine external or government debt, regardless of their currency of denomination - even though most of the external debt is denominated in dollars. The exceptions are Eichengreen and Luengnaruemitchai (2004), who focus on advanced economies bonds denominated in domestic currency; Forslund, Lima, and Panizza (2011), who look at the share of public debt denominated in domestic currency for a large set of developing countries; and Mu, Phelps, and Stotsky (2013), who analyze the bond market capitalization in local currency for Sub-Saharan African countries. Our paper distinguishes between external debt, government debt, and external government debt. However, due to data limitations, it does not examine currency denomination.

With respect to country and time coverage, the existing literature is quite varied. None of the papers focus specifically on frontier LIDCs for the sample period 1998-2016. Our paper is the first to systematically document the debt build-up of frontier LIDCs over the last six

\footnotetext{
${ }^{5}$ A reversal of capital flows could also have adverse impacts on other sectors (for example, the banking sector), which is beyond the scope of this paper.
} 
years and examine its potential drivers. ${ }^{6}$ The closest paper to our country sample and period is Chiminya, Dunne, and Nikolaidou (2018), who analyze the Sub-Saharan countries' external debt-to-GDP ratio over 1975-2012 and consider both economic and political determinants. They find that in addition to economic determinants (GDP growth, trade openness, gross capital formation and real interest rate), political variables (the regime type, electoral competitiveness, whether a country is a presidential or a parliamentary system, and executive constraints) are also correlated with the external debt-to-GDP ratio.

As for methodologies, most of the cross-country studies use fixed or random effects panel regressions, while most of the single-country studies use autoregressive distributed lag models. Since this paper focuses on a set of heterogenous countries, it runs panel regressions which include country fixed effects. Fixed effects allow for the removal of country-specific effects that should not affect the correlations we are interested in.

Given the focus of our paper, we include variables capturing both global as well as countryspecific factors, which are potentially correlated with external and government debt. To our knowledge, there is no other paper studying the effect of global factors - and specifically the Federal funds rate and the commodity price-on debt aggregates, as this paper does. In terms of explanatory variables, different papers choose different variables depending on the specific debt variable analyzed. Usually, regressors such as real GDP growth and fiscal balance are found to correlate negatively with debt-to-GDP ratios, and nominal exchange rate to correlate positively with the external debt-to-GDP ratio. Other regressors vary according to the debt aggregate used as dependent variable, i.e. whether external debt, government debt, or debt denominated in domestic currency, as well as whether the analysis focuses on a single country or it is done at cross-country level. In general, studies include indicators of economic growth, fiscal needs, measures of openness, financial depth, and political stability.

\section{THE RECENT DEBT BUILD-UP IN FRONTIER LIDCs: STYLIZED FACTS}

This section illustrates stylized facts on the debt build-up in frontier LIDCs, as well as potential global and country-specific determinants of the debt build-up. We present the data as cross-country unweighted averages at annual frequency. All data sources and definitions are described in detail in Appendix 2.

\footnotetext{
${ }^{6}$ In the papers by the IMF (2018) and the IMF and World Bank (2018), authors also witness an increase in debt and warn against rising debt vulnerabilities in LIDCs. However, while these two papers focus on a wider and more heterogeneous set of countries, our paper analyses a more homogenous set of countries and conducts an econometric analysis of their debt determinants.
} 


\section{A. Descriptive Statistics of Our Sample}

Our analysis focuses on a set of 18 countries, which belong to at least one of the two following categories: (i) they are classified as a frontier LIDC by IMF (2014); or (ii) they are Poverty Reduction and Growth Trust (PRGT)-eligible countries that have issued sovereign bonds over 2014-17. Table 1 summarizes our sample of countries. Despite being a sovereign bond issuer, Mongolia has been dropped from our sample because of data limitations on government debt, which is one of our main variables of analysis. We focus on this specific set of countries because of the particularly stark

\begin{tabular}{|lcc|}
\hline \multicolumn{3}{|c|}{ Table 1. Sample of Countries } \\
\hline Country & Frontier LIDCs & Past Bond Issuers \\
\hline Bangladesh & $\checkmark$ & \\
Bolivia & $\checkmark$ & $\checkmark$ \\
Cameroon & & $\checkmark$ \\
Congo, Republic of & & $\checkmark$ \\
Côte d'lvoire & $\checkmark$ & $\checkmark$ \\
Ethiopia & & $\checkmark$ \\
Ghana & $\checkmark$ & $\checkmark$ \\
Honduras & $\checkmark$ & $\checkmark$ \\
Kenya & $\checkmark$ & $\checkmark$ \\
Mozambique & $\checkmark$ & \\
Nigeria & $\checkmark$ & $\checkmark$ \\
Papua New Guinea & $\checkmark$ & $\checkmark$ \\
Rwanda & & \\
Senegal & $\checkmark$ & $\checkmark$ \\
Tanzania & $\checkmark$ & $\checkmark$ \\
Uganda & $\checkmark$ & \\
Vietnam & $\checkmark$ & \\
Zambia & $\checkmark$ & \\
\hline Sources: Bloomberg; and IMF, 2014. & \\
\hline
\end{tabular}
increase in debt that frontier LIDCs have been facing over the last years. As most of these countries have access to international financial markets, they were able to sharply increase their borrowings and are now more vulnerable to any reversal of capital flows. Given the new challenges that the currently changing global environment is posing, it is essential to understand the drivers of the recent debt build-up and assess potential future vulnerabilities.

Table 2 provides an overview of the main variables of interest for our sample of countries. The second column shows whether a country has been under a financial (Fin.) or non-financial (Nonfin.) program with the IMF over the period 2012-17. Nine countries have been engaged in a financial program, two in a non-financial program, and seven have not had any program engagement since 2012 . The third column reports on countries that benefited from debt relief under the HIPC Initiative. Most of the countries in the sample received debt relief by mid-2000. The fourth column indicates whether countries are commodity exporters. Six countries in our sample are classified as commodity exporters. The fifth and the sixth columns show the external debt-to-GDP ratios for 2012 and 2017, respectively, while the two last columns show the government debt-to-GDP ratios. Over the period 2012-17, the external debt-to-GDP ratio has increased from 30.4 percent to 49.4 percent of GDP on average, while the government debt-to-GDP ratio has risen from 31.8 percent to 53.1 percent of GDP on average. All countries except Bangladesh, Côte d'Ivoire and Papua New Guinea have faced an increase in their external debt-to-GDP ratios. The debt build-up has been particularly stark for Republic of Congo, Mozambique, and Zambia. 


\begin{tabular}{|c|c|c|c|c|c|c|c|}
\hline \multirow{2}{*}{ Country } & \multirow{2}{*}{$\begin{array}{c}\text { IMF program } \\
\text { Fin./ Nonfin./None } \\
\text { from } 2012\end{array}$} & \multirow[t]{2}{*}{$\begin{array}{c}\text { HIPC } \\
\text { Completion }\end{array}$} & \multirow[t]{2}{*}{$\begin{array}{l}\text { Commodity } \\
\text { Exporter }\end{array}$} & \multicolumn{2}{|c|}{$\begin{array}{l}\text { External Debt } \\
\text { (percent GDP) }\end{array}$} & \multicolumn{2}{|c|}{$\begin{array}{c}\text { Gov. Debt } \\
\text { (percent GDP) }\end{array}$} \\
\hline & & & & 2012 & 2017 & 2012 & 2017 \\
\hline Bangladesh & Fin. & & & 16.76 & 13.79 & 36.22 & 32.41 \\
\hline Bolivia & None & Jun. 2001 & $\checkmark$ & 18.31 & 32.89 & 35.39 & 49.70 \\
\hline Cameroon & Fin. & Apr. 2006 & & 8.22 & 23.13 & 15.41 & 38.22 \\
\hline Congo, Rep. of & None & Jan. 2010 & $\checkmark$ & 25.91 & 82.58 & 28.58 & 119.07 \\
\hline Côte d'Ivoire & Fin. & Jun. 2012 & & 44.78 & 42.17 & 45.04 & 46.83 \\
\hline Ethiopia & None & Apr. 2004 & & 20.60 & 33.53 & 37.65 & 56.22 \\
\hline Ghana & Fin. & Jul. 2004 & & 25.17 & 40.48 & 47.94 & 71.83 \\
\hline Honduras & Fin. & Apr. 2005 & & 26.14 & 37.43 & 29.76 & 39.48 \\
\hline Kenya & Fin. & & & 30.23 & 46.65 & 43.87 & 57.97 \\
\hline Mozambique & Fin. & Sep. 2001 & $\checkmark$ & 69.69 & 147.40 & 40.09 & 102.24 \\
\hline Nigeria & None & & $\checkmark$ & 8.07 & 13.52 & 12.74 & 21.78 \\
\hline Papua New Guinea & None & & $\checkmark$ & 76.73 & 72.45 & 19.12 & 32.60 \\
\hline Rwanda & Fin. & Apr. 2005 & & 20.24 & 40.12 & 19.96 & 40.59 \\
\hline Senegal & Nonfin. & Apr. 2004 & & 47.28 & 67.12 & 32.78 & 48.33 \\
\hline Tanzania & Fin. & Nov. 2001 & & 25.30 & 34.03 & 29.15 & 36.94 \\
\hline Uganda & Nonfin. & May 2000 & & 28.19 & 42.67 & 24.60 & 40.03 \\
\hline Vietnam & None & & & 37.46 & 45.54 & 48.38 & 58.23 \\
\hline Zambia & None & Apr. 2005 & $\checkmark$ & 17.30 & 72.84 & 25.42 & 62.75 \\
\hline Average & & & & 30.35 & 49.35 & 31.78 & 53.07 \\
\hline
\end{tabular}

Sources: IMF, 2014 and 2017; and IMF World Economic Outlook database, as of June 2018.

Note: The classification of countries according to engagement in an IMF program concerns the period 2012-17. Moreover, data on external and government debt for 2017 are either estimates or projections.

\section{B. Debt Build-up over 2012-17}

Frontier LIDCs have faced a stark increase in their debt burden since 2012. After the HIPC Initiative, debt burdens in most of the frontier LIDCs had declined significantly, but since 2012, both external and general government gross debt started rising (Figure 1). The breakdown of external debt by type of debtor into private and official shows that both

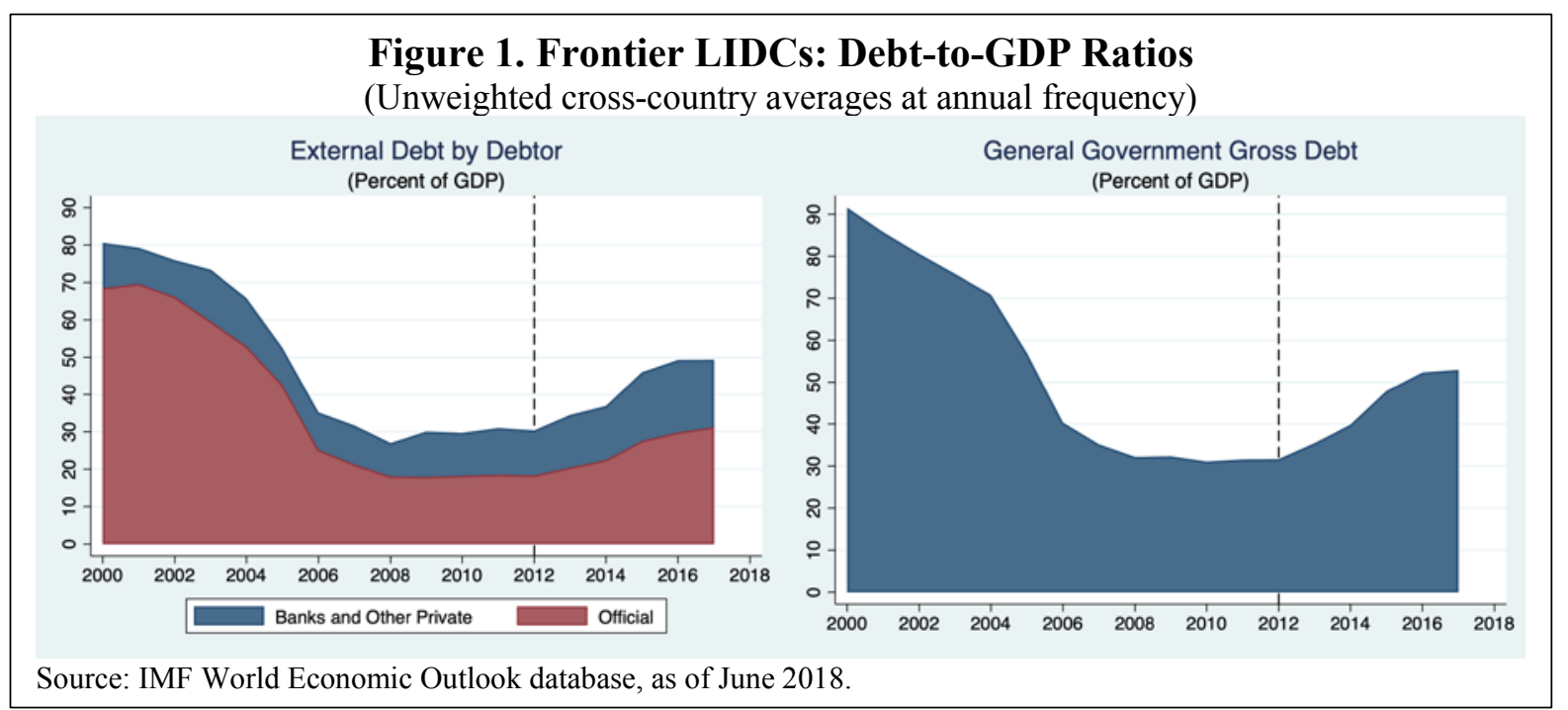


components have contributed to the increase in external debt. General government gross debt exhibits a similar pattern in terms of stark growth. ${ }^{7}$ Further insights on the dispersion of debtto-GDP ratios across countries are presented in Appendix 3.

Focusing on external debt characteristics, the share of concessional financing is dropping, while the maturity is mainly long term. As illustrated by Figure 2, concessional financing as a share of external debt dropped from 61 percent in 2000 to 50 percent in 2016. The fact that a higher share of debt is issued at non-concessional terms may increase the cost of financing for frontier LIDCs countries. At the same time, the maturity of external debt remains mainly long term, even though the share of short-term debt is slightly increasing.

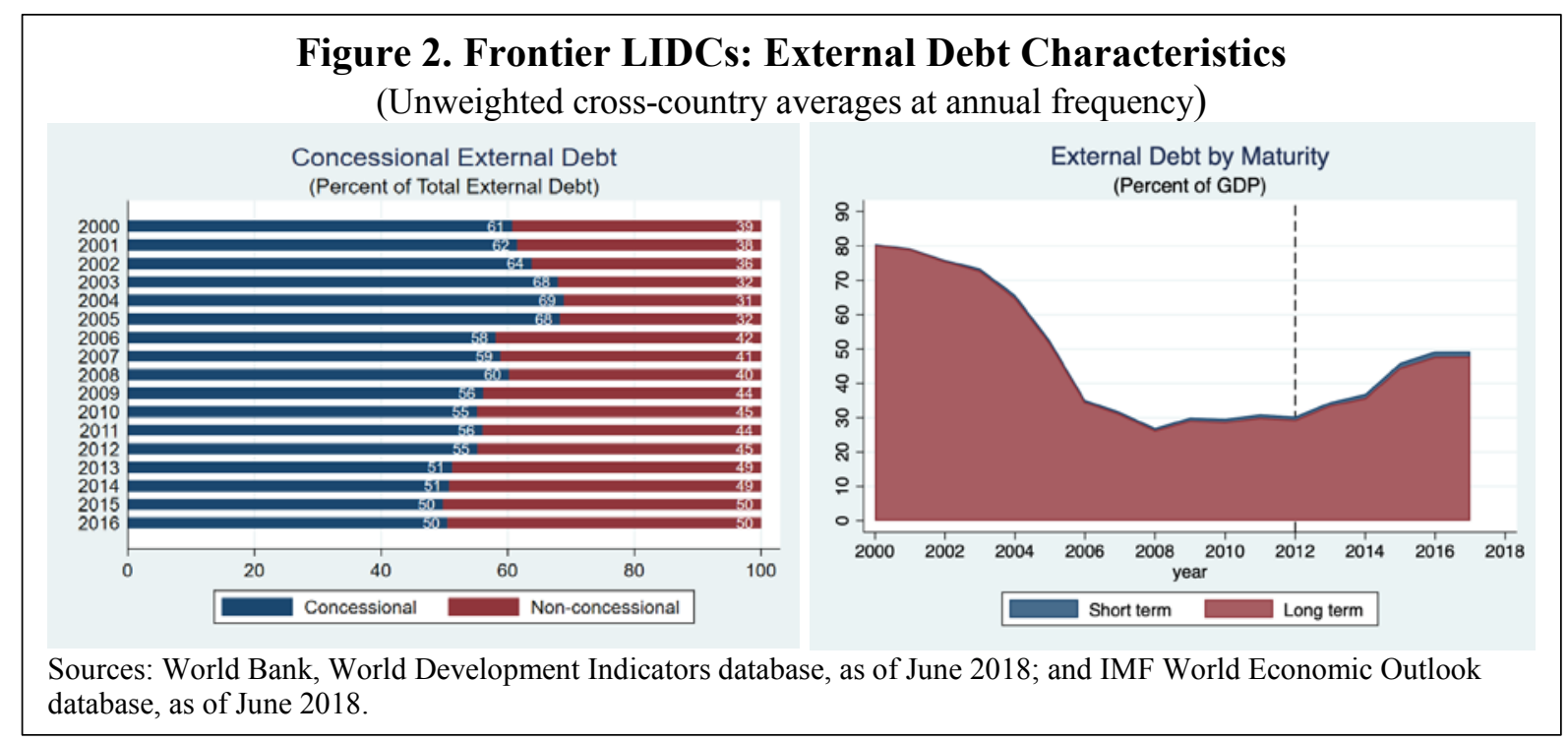

The interest rate burden has significantly increased for frontier LIDCs since 2012. Interest payments on external debt have more than doubled from a cross-country average of 0.5 percent of GDP in 2012 to 1.4 percent of GDP in 2017. Similarly, general government debt interest payments have increased from an average of 1.1 percent of GDP in 2010 to 2.3 percent of GDP in 2017 (Figure 3). This rise is due to an increase both in the

\section{Figure 3. Frontier LIDCs: Interest Rate Burden}

(Unweighted cross-country averages at annual frequency)

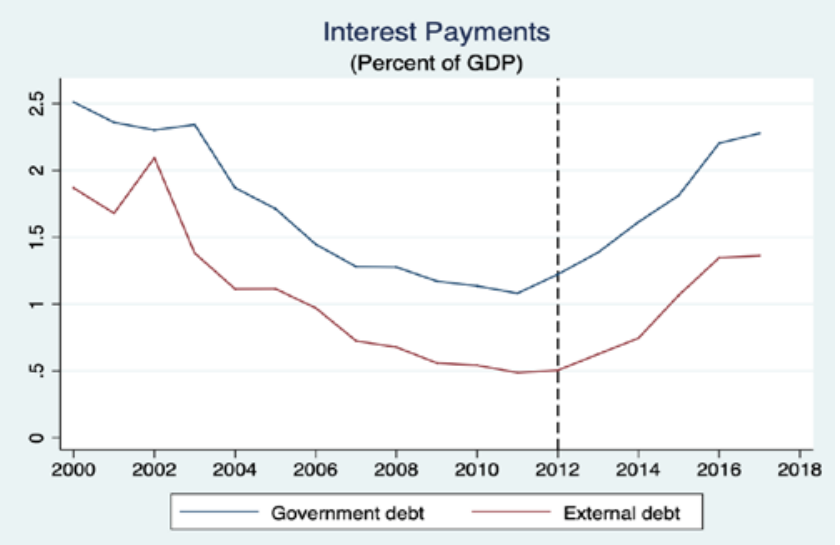

Source: IMF World Economic Outlook database, as of June 2018.

${ }^{7}$ For a detailed description of debt flows over 1981-2006, see Dorsey and others (2008). 
volume of debt and in the interest rate that frontier LIDCs have to pay (see the rise in the effective interest rate shown in Figure 5).

\section{Global and Country-specific Factors Affecting Debt Build-up}

Global financing conditions have been very favorable over the last ten years and commodity prices have been rebounding after the 2016 trough. The Federal Funds rate had been at its alltime low from end-2008 to end-2015 and started rising henceforth (Figure 4). This global low-interest rate environment might have pushed investors in search of higher returns to invest in frontier LIDCs bonds, thus contributing to the debt build-up in these countries. Examining global commodity prices, the commodity price index peaked at 198 in 2011 , dropped to 117 in 2016, and started rebounding since then. However, it remains at a much lower value than its 2011 peak. Since some countries in our sample are commodity exporters, the commodity price drop could be another factor contributing to the debt increase over the period 2012-17.

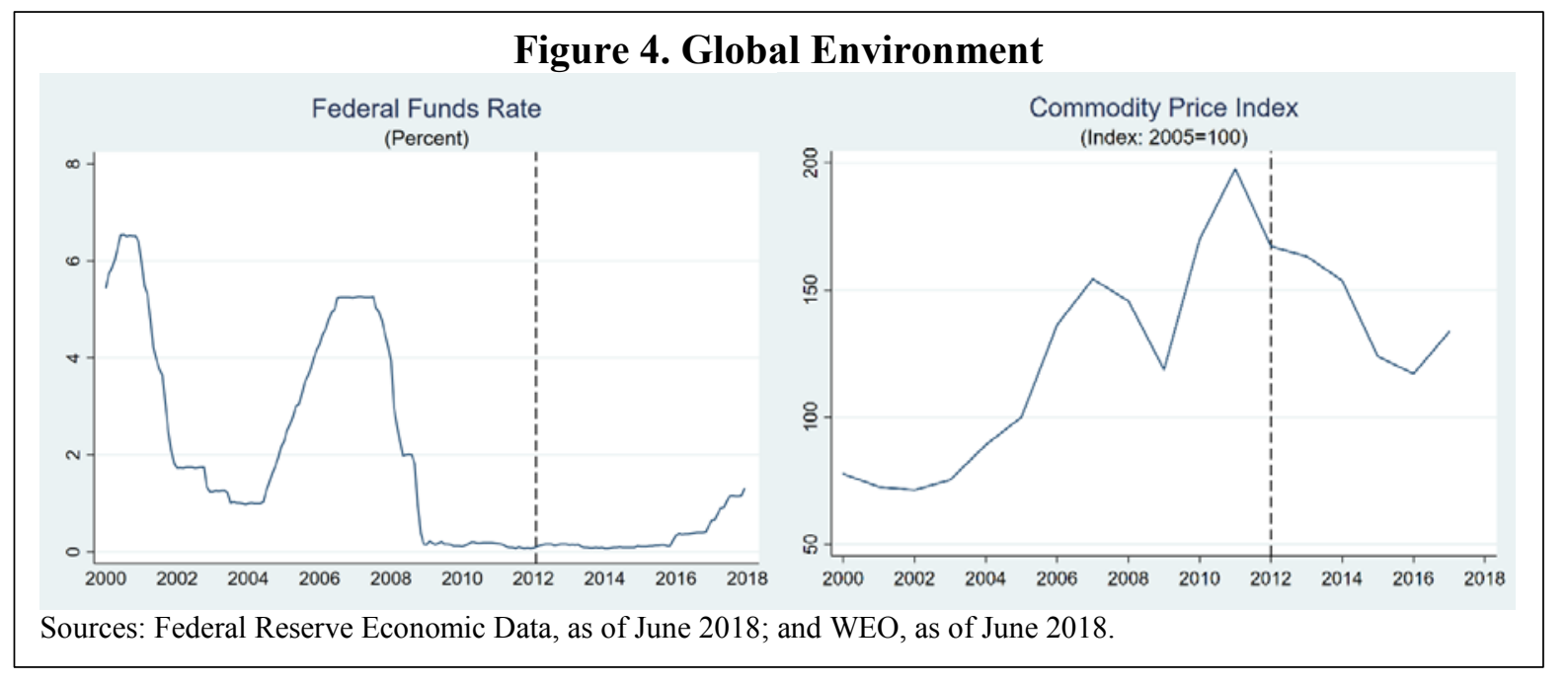

The cost of financing rose over the period 2012-17, while foreign direct investment (FDI) inflows peaked and dropped back to 2012 levels during this period. The effective interest rate has increased by 1.1 percentage points for external debt and 0.5 percentage points for public debt over the period 2012-17, showing that borrowing has become more expensive for frontier LIDCs over the last seven years (Figure 5). Looking at financial inflows, the righthand side of Figure 5 shows both portfolio and FDI inflows. While portfolio inflows have remained broadly stable, FDI inflows have increased up to 2016, and then sharply dropped. 


\section{Figure 5. Frontier LIDCs: Financial Cost and Financing Inflows}

(Unweighted cross-country averages at annual frequency)
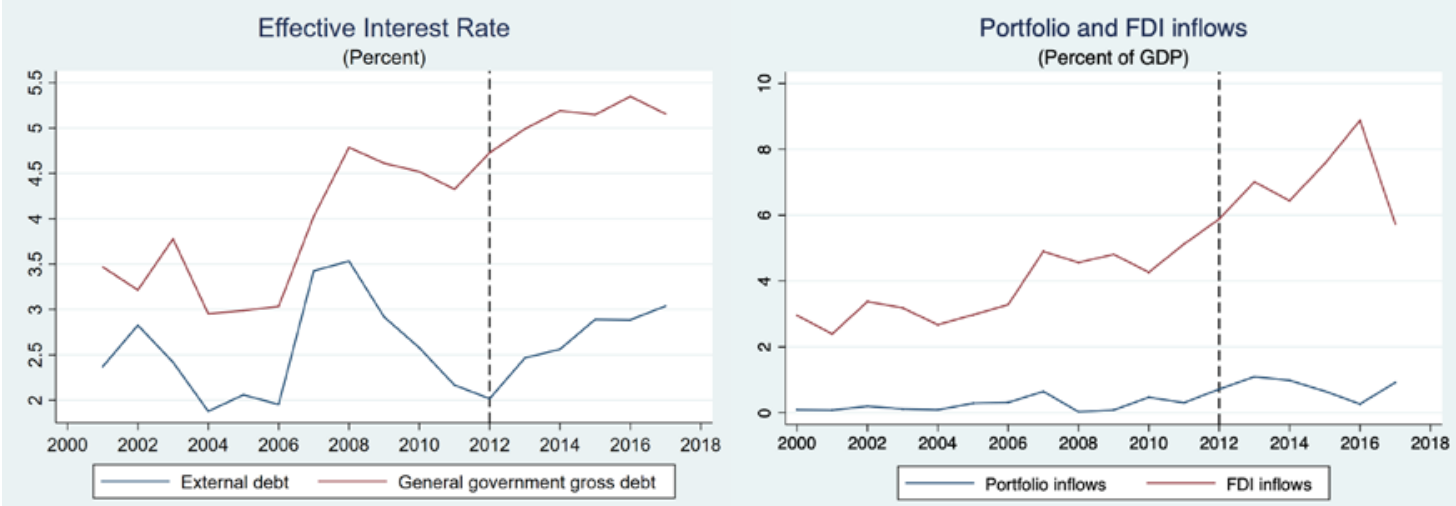

Source: IMF World Economic Outlook database, as of June 2018.

Current account and fiscal deficits peaked in 2015 but decreased over the last two years. After reaching a peak at 8 percent of GDP in 2015, the average current account deficit contracted over the period 2015-17 (Figure 6). The current account fluctuations have mainly been driven by the goods and services account, with the primary and secondary income accounts remaining stable. On average, both imports and exports have decreased from 2012.

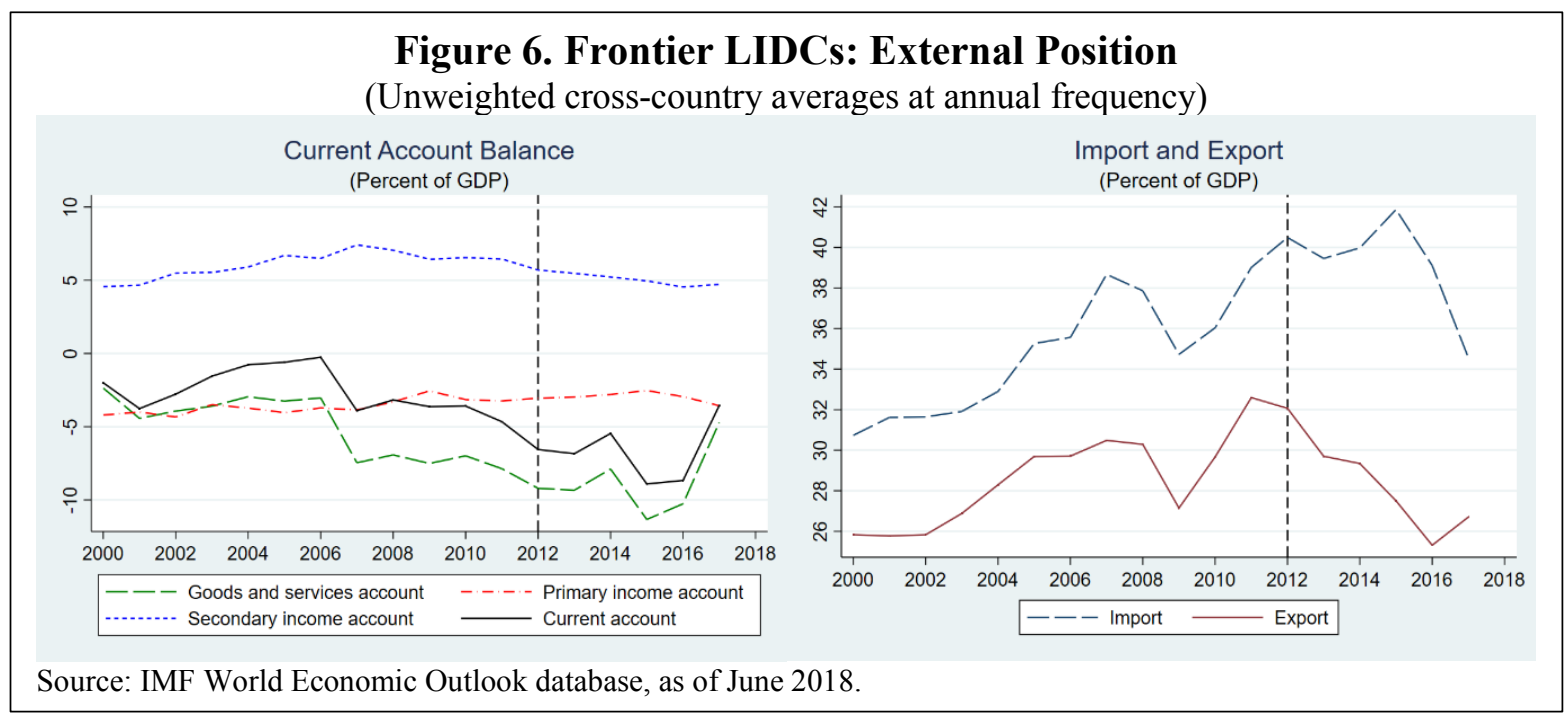


Focusing on the fiscal balance, the cross-country average of the primary fiscal deficit reached 4.2 percent of GDP in 2015, before narrowing over the last couple of years (Figure 7). When examining the components of the fiscal balance, both expenditure and revenue increased until 2014, and started narrowing afterwards (Figure 8). In particular, government expenditure in nonfinancial assets (capital spending) increased by 3 percentage points from 2010 to 2014 but narrowed since then by roughly the same amount.

Figure 7. Frontier LIDCs: Fiscal Position

(Unweighted cross-country averages at annual frequency)

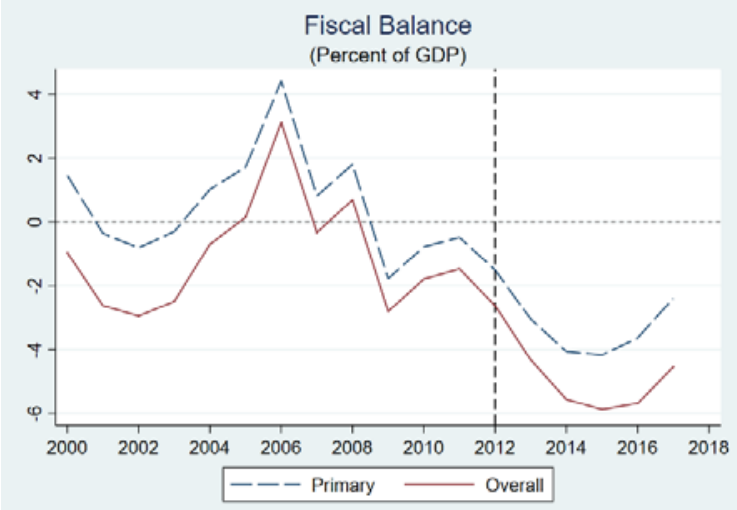

Source: IMF World Economic Outlook database, as of June 2018.

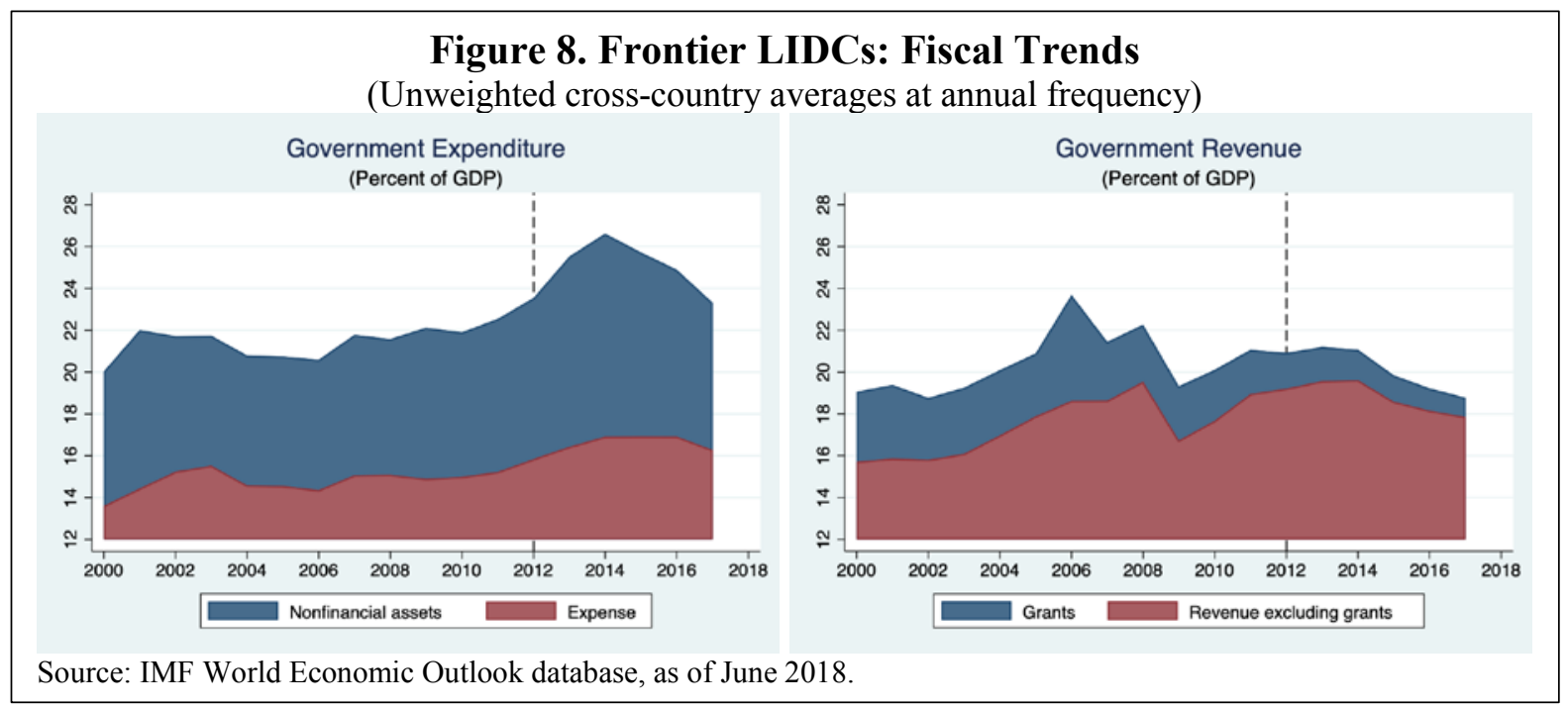

\section{Main takeaways}

Both external and government debt of frontier LIDCs have been growing steadily since 2012 . The share of external debt contracted at concessional terms has been shrinking, thus suggesting an ongoing change in the debt composition. Interest rate payments have risen due to the increase in the stock of debt as well as in the effective interest rate. The global financial environment has been particularly favorable over the analyzed period, yet the interest rate on debt that these countries face has surged, suggesting that the interest rate rise is not due to the global financial environment, but to other factors. The drop in commodity prices might have contributed to a further increase in debt for commodity exporters. The sharp external and government debt build-up is mirrored by the widening of the current account and the fiscal deficits. These two deficits started narrowing only in 2017. 


\section{GLOBAL OR COUNTRY-SPECIFIC FACTORS?}

This section carries out a panel regression analysis to show which global and countryspecific factors influence the debt-to-GDP ratios over the period 1998-2016.

\section{A. Methodology and Estimation}

We estimate the following model:

Debt_to_GDP $P_{i, t}=\alpha_{i}+\beta_{g} *$ Global $_{i, t}+\beta_{c} *$ Country_specific $c_{i, t}+\varepsilon_{i, t}$.

where $i$ indicates the country and $t$ the year. We estimate equation (1) introducing country fixed effects $\alpha_{i}$ and we cluster standard errors at the country level. We estimate equation (1) first for the sample period 1998-2016 and then for the two subsamples 1998-2011 and 2012$16 .{ }^{8}$ The sample split helps us better understand potential drivers of the increase in debt since 2012.

We estimate regression (1) for the following debt aggregates: external debt (including private and official) and general government debt (encompassing domestic and external). We then further disaggregate external debt into private external debt and general government external debt.

We discuss below the global and country-specific explanatory variables that we include:

\section{Global factors}

Federal Funds rate. This is a proxy for the global financial cycle. As is well documented in the capital flows literature (e.g., Fratzscher, 2012), an environment of low interest rates as observed over the last decade could push investors to look for high return assets. This search for yield may have generated substantial capital inflows toward frontier LIDCs, which recently started issuing debt, and contributed to their debt build-up. ${ }^{9}$ The inverse relationship between global yields and the debt-to-GDP ratio is already documented for Asian countries by Eichengreen and Luengnaruemitchai (2004), who find a negative correlation between the interest rate spread (interbank rate minus LIBOR) and bond market capitalization as a share of GDP.

Global commodity price index. This index is used to control for global commodity price dynamics. Since many countries in our sample are commodity exporters, fluctuations in commodity prices could affect their debt-to-GDP ratios. In particular, an increase in commodity prices would help them reduce their debt-to-GDP ratios, while a decrease could

\footnotetext{
${ }^{8}$ Since capital account openness is only available up to 2016, we could not extend our analysis to 2017 .

${ }^{9}$ To account for financial market uncertainty, we also included the CBOE Volatility index (VIX), the world's barometer for equity market volatility, but it did not seem to correlate with the debt-to-GDP ratios of our country sample. Therefore, we have excluded it from our baseline regressions.
} 
lead to higher debt-to-GDP ratios. Our results are robust also when we substitute the global commodity price index, which does not include oil, with a crude oil index.

\section{Country-specific factors}

Real GDP growth. Real GDP growth is an important determinant of debt dynamics as it affects the denominator of the debt-to-GDP ratio. ${ }^{10} \mathrm{We}$ expect that countries with a higher real GDP growth will have a lower debt-to-GDP ratio.

Broad money growth. This is a proxy for financial development. It is argued that countries with a deeper financial market would find it easier to raise capital by issuing debt (Woo, 2003). We expect to find a positive correlation between broad money growth and the government debt-to-GDP ratio.

Primary fiscal balance-to-GDP. This is a measure of primary fiscal needs, excluding interest payments. It is a direct determinant of public debt dynamics (Escolano, 2010) and affects external debt through its public component. We expect it to be negatively correlated with the debt-to-GDP ratio.

Nominal exchange rate. We define the nominal exchange rate as domestic currency per dollar. We expect that a depreciation of the currency, i.e. an increase in the nominal exchange rate, leads to an increase in the debt-to-GDP ratio.

Openness. To measure how the openness of a country affects its debt-to-GDP ratio, we include two variables: the growth rate of the terms of trade and the capital account openness. Changes in the relative price of exports can affect the decision to issue new debt, both domestically and externally. Even though, theoretically, the current account could adjust in either direction in response to a positive terms-of-trade shock (e.g. Cashin and McDermott, 1998), empirical evidence shows that positive terms-of-trade shocks lead to a current account improvement. ${ }^{11}$ Hence, we expect a higher terms of trade growth to be associated with lower external and government debt-to-GDP ratios. As for the capital account openness, we measure it through the Chinn-Ito index (Chinn and Ito, 2006). There is empirical evidence that high capital account openness facilitates financial development and capital inflows. We expect that high capital account openness results in higher debt levels.

Institutional and political indicators. These two indices control for institutional and political factors, which could potentially correlate with debt-to-GDP ratios. ${ }^{12}$ Both the corruption and the political risk indices are subcomponents of the International Country Risk Guide index. Higher values of corruption and political risk indices mean better institutional quality and less political instability. The correlation between each of the two indices and debt-to-GDP

\footnotetext{
${ }^{10}$ See Anaya and Pienkowski (2015) for an analysis of debt dynamics concerning public debt.

${ }^{11}$ See Adler, Magud, and Werner (2017) for an empirical analysis on terms of trade cycles and the external adjustment.

${ }^{12}$ See Guscina (2008) for an analysis on the impact of political and institutional factors on the structure of government debt in emerging markets.
} 
ratios is ambiguous. While lower corruption and higher political stability could help countries tap financial markets, more corruption and instability could lead to wider fiscal imbalances and higher government debt.

Debt-to-GDP ratio persistence. This is proxied by the lagged debt-to-GDP ratio for each debt aggregate (external, government, and external government). As shown in Figure 2, most of the external debt is long term. ${ }^{13}$ Long-term maturity results in a high persistence of debt stocks, which in turn, leads to persistent debt-to-GDP ratios if GDP is not too volatile. To account for this, we include the lagged debt-to-GDP ratio. We expect the correlation between the debt-to-GDP ratio and its lag to be positive.

IMF engagement. We include a dummy which is equal to one in the years when a country is engaged in an IMF program (financial or non-financial) and zero otherwise. This is to estimate whether there is any correlation between the IMF intervention and debt-to-GDP ratios. ${ }^{14}$ Finally, since some countries in our sample received debt relief under the HIPC Initiative, we also include a HIPC dummy variable as in Marcelino and Hakobyan (2014). Our HIPC dummy is equal to zero before the completion date of the HIPC Initiative and to one for the post-completion period. ${ }^{15}$ The HIPC dummy is zero for countries which have not benefitted from HIPC debt relief.

\section{Results: full sample}

Columns (1) and (3) in Table 3 show our baseline results of the regression estimation for the external and the government debt-to-GDP ratios, respectively, over the full sample period 1998-2016.

- Global factors. The commodity price index is negatively and significantly correlated with debt-to-GDP ratios. In fact, many countries in our sample are commodity producers, thus benefitting from increases in global commodity prices. The Federal Funds rate is significantly correlated with the external debt-to-GDP ratio over the full sample, but not with the government debt-to-GDP ratio.

- Country-specific factors. Real GDP growth is negatively and significantly correlated with the debt-to-GDP ratio, suggesting that a stronger GDP growth helps reduce the debt-toGDP ratio, everything else equal. Moreover, we find that the primary fiscal balance as a share of GDP is negatively and significantly correlated with the debt-to-GDP ratio. Looser fiscal policy increases not only the government debt-to-GDP ratio, which is directly reflected by the primary balance, but also the external debt-to-GDP ratio. In addition, the debt-to-GDP ratio is persistent as we find a positive and significant correlation between the debt-to-GDP ratio and its first lag for both debt aggregates. Nominal exchange rate is not significantly correlated with debt-to-GDP ratios. Variables

\footnotetext{
${ }^{13}$ We do not have data on government debt maturity.

14 The relationship could go either way. The IMF intervention could help a country reduce its debt-to-GDP ratios, but at the same time, a country could engage in an IMF program because it has high debt-to-GDP ratios.

${ }^{15}$ See Table 2 for the countries that reached the HIPC completion point.
} 
referring to financial development, openness and institutional factors do not seem to be significantly correlated with debt-to-GDP ratios. Finally, columns (2) and (4) report results of regressions where we have added the IMF and HIPC dummies. We find that when countries are under an IMF program, they have lower debt-to-GDP ratios. We also find that when countries have benefitted from HIPC debt relief, they have a lower government debt-to-GDP ratio.

\section{Results: subsamples}

Tables 4-6 report results for the same set of regressions as Table 3 for the two subsample periods 1998-2011 and 2012-16, and for the external debt breakdown.

- Global factors. The commodity price index is still negatively and significantly correlated with both external and government debt-to-GDP ratios in both subsamples, even though the correlation becomes larger in magnitude in 2012-16. Moreover, in 2012-16, the correlation between the Federal Funds rate and the debt-to-GDP ratios is significant and large in absolute value (Table 5). This suggests that the global financial cycle, as proxied by the U.S. policy rate, is strongly correlated with the rise in debt-to-GDP ratios that frontier LIDCs are facing and a potentially important determinant of it. The strongest negative correlation is found for the external debt-toGDP ratio, while the correlation with the government debt-to-GDP ratio is about half - although still high in absolute value. The magnitude of the coefficients of the commodity price index and the Federal Funds rate is very large in the subsample 2012-16. This is due to the fact that over these years, interest rates were extremely low, commodity prices dropped sharply and debt skyrocketed, thus resulting in a negative correlation, which is very large in absolute value.

To sharpen our understanding, we further break external debt down into its private and government components. Table 6 shows that the negative and significant correlation with the Federal Funds rate over the period 2012-16 holds for both the private and the government component of external debt.

- $\quad$ Country-specific factors. The correlation of debt-to-GDP ratios with the primary balance and real GDP growth is negative and highly significant in both subsamples (Tables 4-5). For external debt, we also find that a higher capital account openness is positively and significantly correlated with higher external debt-to-GDP ratio over the period 2012-16. Additionally, we find that countries that received debt relief under the HIPC Initiative have a lower government debt-to-GDP ratio for the sample period 1998-2011, which is the period when the debt relief was carried out. However, the correlation becomes positive over the period 2012-16, suggesting that countries which have had debt relief started accumulating new government debt. 
Table 3. Frontier LIDCs: Debt Determinants: 1998-2016

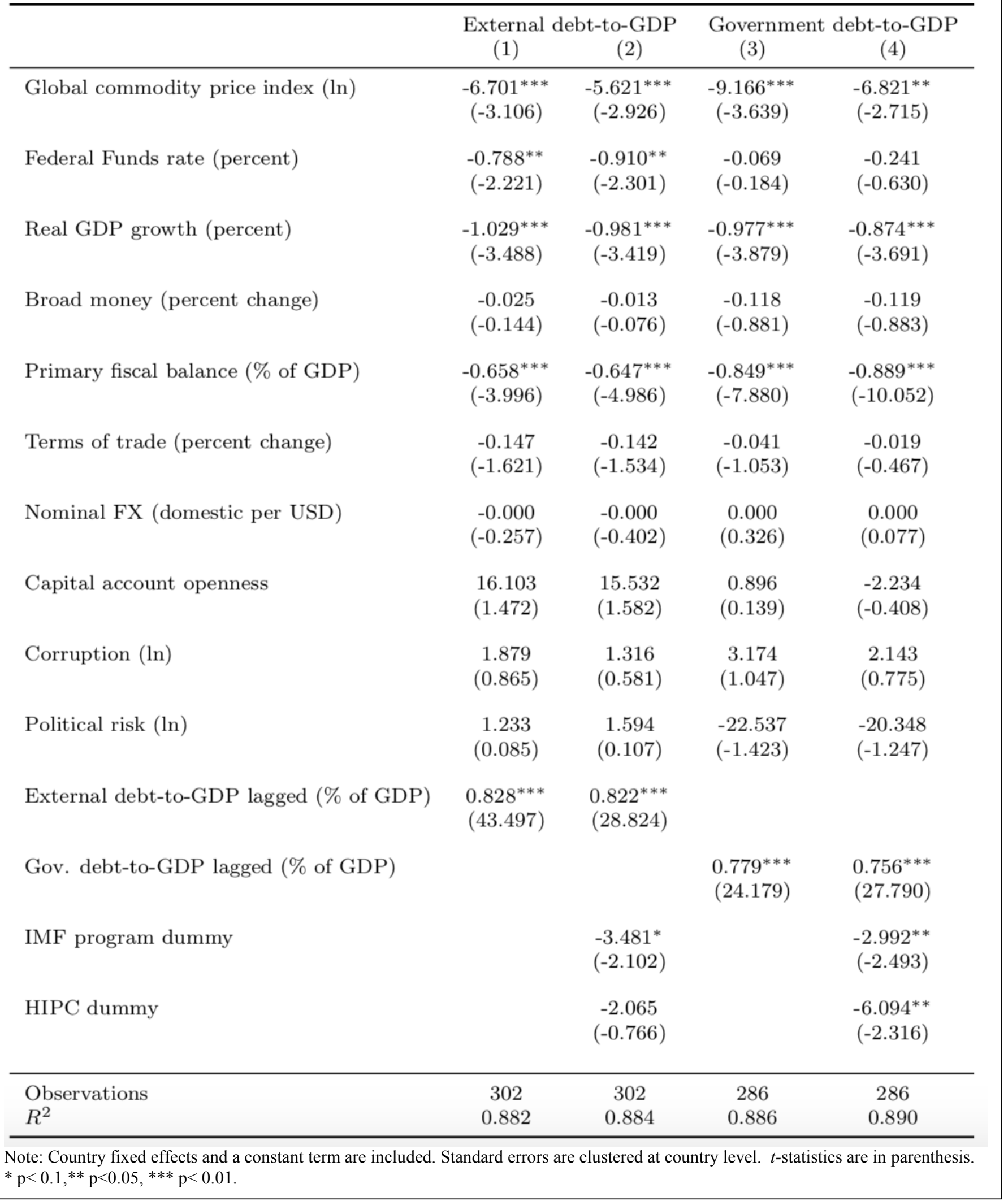


Table 4. Frontier LIDCs: Debt Determinants: 1998-2011

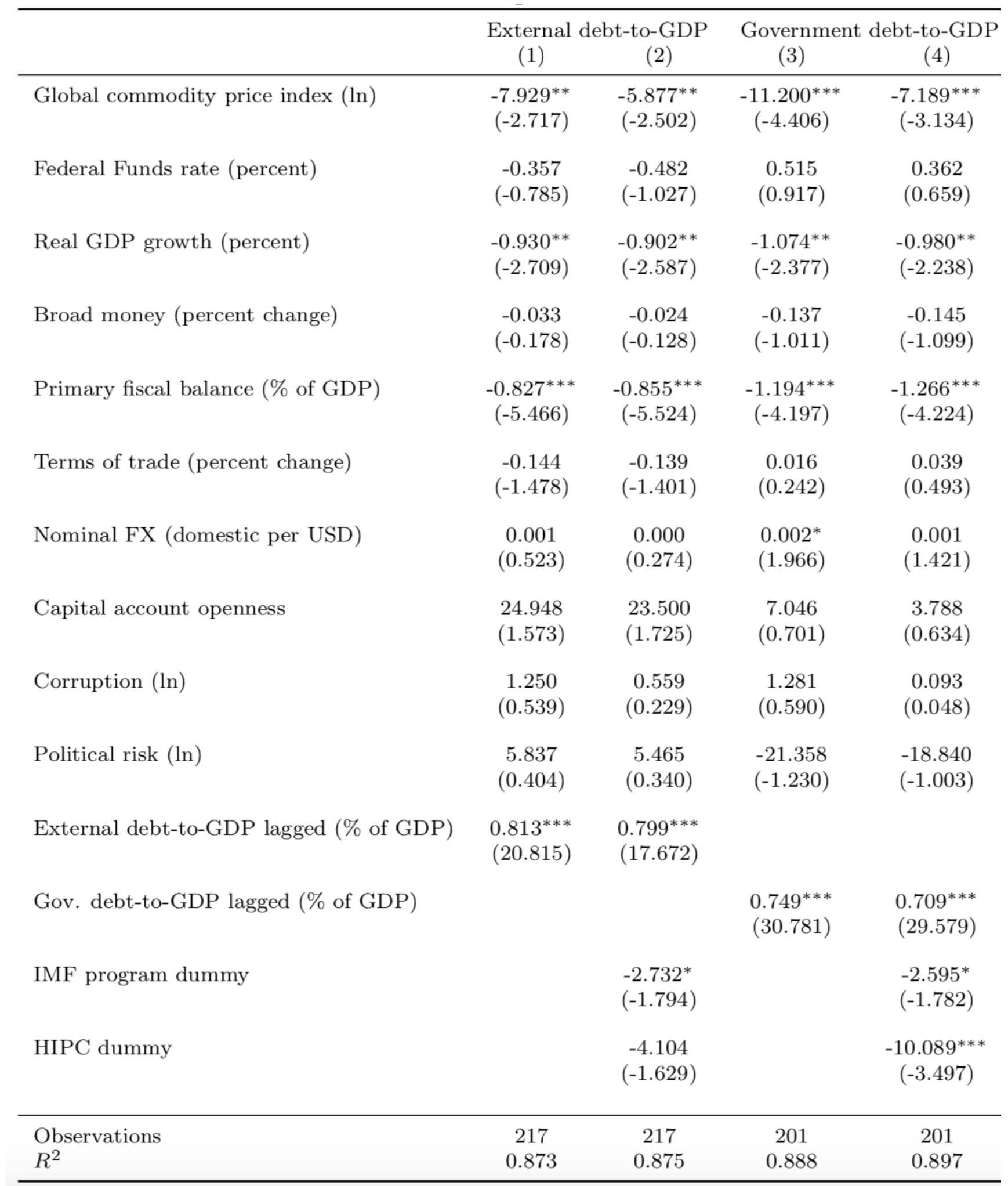

Note: Country fixed effects and a constant term are included. Standard errors are clustered at country level. $t$-statistics are in parenthesis. $* \mathrm{p}<0.1, * * \mathrm{p}<0.05, * * * \mathrm{p}<0.01$ 
Table 5. Frontier LIDCs: Debt Determinants: 2012-16

\begin{tabular}{|c|c|c|c|c|}
\hline & \multicolumn{2}{|c|}{ External debt-to-GDP } & \multicolumn{2}{|c|}{ Government debt-to-GDP } \\
\hline & (1) & $(2)$ & (3) & $(4)$ \\
\hline Global commodity price index $(\ln )$ & $\begin{array}{c}-31.352^{* *} \\
(-2.371)\end{array}$ & $\begin{array}{l}-28.648^{*} \\
(-2.109)\end{array}$ & $\begin{array}{c}-23.709^{* *} \\
(-2.219)\end{array}$ & $\begin{array}{c}-17.662^{*} \\
(-1.831)\end{array}$ \\
\hline Federal Funds rate (percent) & $\begin{array}{c}-28.252^{* * *} \\
(-3.489)\end{array}$ & $\begin{array}{c}-31.837^{* * *} \\
(-3.487)\end{array}$ & $\begin{array}{c}-13.253^{*} \\
(-2.119)\end{array}$ & $\begin{array}{c}-15.922^{* *} \\
(-2.137)\end{array}$ \\
\hline Real GDP growth (percent) & $\begin{array}{c}-1.740^{* * *} \\
(-3.430)\end{array}$ & $\begin{array}{c}-1.609^{* * *} \\
(-3.221)\end{array}$ & $\begin{array}{r}-1.032^{* *} \\
(-2.165)\end{array}$ & $\begin{array}{l}-0.719^{*} \\
(-2.073)\end{array}$ \\
\hline Broad money (percent change) & $\begin{array}{c}-0.103 \\
(-0.362)\end{array}$ & $\begin{array}{c}-0.098 \\
(-0.350)\end{array}$ & $\begin{array}{c}0.032 \\
(0.206)\end{array}$ & $\begin{array}{c}0.013 \\
(0.077)\end{array}$ \\
\hline Primary fiscal balance ( $\%$ of GDP) & $\begin{array}{c}-0.695^{* * *} \\
(-3.843)\end{array}$ & $\begin{array}{c}-0.668^{* * *} \\
(-3.577)\end{array}$ & $\begin{array}{c}-1.090^{* * *} \\
(-5.487)\end{array}$ & $\begin{array}{c}-0.989^{* * *} \\
(-4.887)\end{array}$ \\
\hline Terms of trade (percent change) & $\begin{array}{c}0.066 \\
(0.589)\end{array}$ & $\begin{array}{c}0.072 \\
(0.595)\end{array}$ & $\begin{array}{c}-0.026 \\
(-0.275)\end{array}$ & $\begin{array}{c}-0.053 \\
(-0.687)\end{array}$ \\
\hline Nominal FX (domestic per USD) & $\begin{array}{c}0.002 \\
(0.742)\end{array}$ & $\begin{array}{c}0.003 \\
(1.136)\end{array}$ & $\begin{array}{c}0.001 \\
(0.858)\end{array}$ & $\begin{array}{c}0.002 \\
(1.634)\end{array}$ \\
\hline Capital account openness & $\begin{array}{c}58.792^{* *} \\
(2.805)\end{array}$ & $\begin{array}{c}50.462^{* *} \\
(2.689)\end{array}$ & $\begin{array}{l}23.950 \\
(1.221)\end{array}$ & $\begin{array}{c}9.382 \\
(0.735)\end{array}$ \\
\hline Corruption (ln) & $\begin{array}{c}-4.874 \\
(-0.832)\end{array}$ & $\begin{array}{c}3.378 \\
(0.447)\end{array}$ & $\begin{array}{c}2.605 \\
(0.661)\end{array}$ & $\begin{array}{l}8.335^{*} \\
(1.791)\end{array}$ \\
\hline Political risk (ln) & $\begin{array}{l}-36.233 \\
(-0.562)\end{array}$ & $\begin{array}{l}-29.737 \\
(-0.550)\end{array}$ & $\begin{array}{c}-71.839^{*} \\
(-1.799)\end{array}$ & $\begin{array}{c}-57.355^{*} \\
(-1.973)\end{array}$ \\
\hline External debt-to-GDP lagged ( $\%$ of GDP) & $\begin{array}{c}0.728^{* * *} \\
(3.483)\end{array}$ & $\begin{array}{c}0.797^{* * *} \\
(3.634)\end{array}$ & & \\
\hline Gov. debt-to-GDP lagged ( $\%$ of GDP) & & & $\begin{array}{c}0.776^{* * *} \\
(5.629)\end{array}$ & $\begin{array}{c}0.903^{* * *} \\
(7.773)\end{array}$ \\
\hline IMF program dummy & & $\begin{array}{c}-6.080 \\
(-1.632)\end{array}$ & & $\begin{array}{l}-4.445^{*} \\
(-1.942)\end{array}$ \\
\hline HIPC dummy & & $\begin{array}{c}7.180 \\
(1.611)\end{array}$ & & $\begin{array}{c}17.575^{* * * *} \\
(3.968)\end{array}$ \\
\hline $\begin{array}{l}\text { Observations } \\
R^{2}\end{array}$ & $\begin{array}{c}85 \\
0.758\end{array}$ & $\begin{array}{c}85 \\
0.777\end{array}$ & $\begin{array}{c}85 \\
0.874\end{array}$ & $\begin{array}{c}85 \\
0.898\end{array}$ \\
\hline
\end{tabular}

Note: Country fixed effects and a constant term are included. Standard errors are clustered at country level. $t$-statistics are in parenthesis. $* \mathrm{p}<0.1,{ }^{* *} \mathrm{p}<0.05,{ }^{* * *} \mathrm{p}<0.01$. 
Table 6. Frontier LIDCs: External Debt Determinants: 2012-16

\begin{tabular}{|c|c|c|c|c|}
\hline & \multicolumn{2}{|c|}{$\begin{array}{l}\text { External private debt-to-GDP } \\
(1)\end{array}$} & \multicolumn{2}{|c|}{$\begin{array}{l}\text { External gov. debt-to-GDP } \\
(3)\end{array}$} \\
\hline Global commodity price index $(\ln )$ & $\begin{array}{c}-12.947^{*} \\
(-1.752)\end{array}$ & $\begin{array}{r}-13.442^{*} \\
(-1.761)\end{array}$ & $\begin{array}{l}-22.622^{* * *} \\
(-2.938)\end{array}$ & $\begin{array}{c}-17.806^{* *} \\
(-2.515)\end{array}$ \\
\hline Federal Funds rate (percent) & $\begin{array}{c}-11.883^{* *} \\
(-2.750)\end{array}$ & $\begin{array}{c}-12.671^{* *} \\
(-2.771)\end{array}$ & $\begin{array}{c}-14.746^{* *} \\
(-2.749)\end{array}$ & $\begin{array}{c}-17.737^{* *} \\
(-2.837)\end{array}$ \\
\hline Real GDP growth (percent) & $\begin{array}{r}-1.000^{* *} \\
(-2.614)\end{array}$ & $\begin{array}{r}-0.993^{* *} \\
(-2.558)\end{array}$ & $\begin{array}{r}-0.786^{* *} \\
(-2.473)\end{array}$ & $\begin{array}{r}-0.597^{* *} \\
(-2.474)\end{array}$ \\
\hline Broad money (percent change) & $\begin{array}{c}-0.117 \\
(-0.716)\end{array}$ & $\begin{array}{l}-0.093 \\
(-0.537)\end{array}$ & $\begin{array}{c}-0.081 \\
(-0.800)\end{array}$ & $\begin{array}{c}-0.085 \\
(-0.849)\end{array}$ \\
\hline Primary fiscal balance ( $\%$ of GDP) & $\begin{array}{c}-0.611^{* * *} \\
(-5.100)\end{array}$ & $\begin{array}{c}-0.625^{* * *} \\
(-5.137)\end{array}$ & $\begin{array}{l}-0.100 \\
(-1.091)\end{array}$ & $\begin{array}{l}-0.061 \\
(-0.625)\end{array}$ \\
\hline Terms of trade (percent change) & $\begin{array}{c}0.080 \\
(1.146)\end{array}$ & $\begin{array}{c}0.092 \\
(1.180)\end{array}$ & $\begin{array}{c}0.008 \\
(0.129)\end{array}$ & $\begin{array}{l}-0.011 \\
(-0.200)\end{array}$ \\
\hline Nominal FX (domestic per USD) & $\begin{array}{c}0.001 \\
(0.391)\end{array}$ & $\begin{array}{c}0.001 \\
(0.418)\end{array}$ & $\begin{array}{c}0.000 \\
(0.030)\end{array}$ & $\begin{array}{c}0.002 \\
(1.099)\end{array}$ \\
\hline Capital account openness & $\begin{array}{c}51.875^{* * *} \\
(3.786)\end{array}$ & $\begin{array}{l}52.860^{* * *} \\
(3.834)\end{array}$ & $\begin{array}{l}16.019 \\
(1.250)\end{array}$ & $\begin{array}{c}2.731 \\
(0.296)\end{array}$ \\
\hline Corruption (ln) & $\begin{array}{l}-4.607 \\
(-0.866)\end{array}$ & $\begin{array}{l}-1.568 \\
(-0.245)\end{array}$ & $\begin{array}{l}-1.760 \\
(-0.370)\end{array}$ & $\begin{array}{l}2.751 \\
(0.721)\end{array}$ \\
\hline Political risk (ln) & $\begin{array}{c}-0.393 \\
(-0.012)\end{array}$ & $\begin{array}{l}-0.643 \\
(-0.021)\end{array}$ & $\begin{array}{l}-46.487 \\
(-1.350)\end{array}$ & $\begin{array}{l}-33.428 \\
(-1.370)\end{array}$ \\
\hline External private debt-to-GDP lagged ( $\%$ of GDP) & $\begin{array}{c}0.557^{* *} \\
(2.394)\end{array}$ & $\begin{array}{c}0.567^{* *} \\
(2.357)\end{array}$ & & \\
\hline External gov. debt-to-GDP lagged ( $\%$ of GDP) & & & $\begin{array}{c}0.608^{* * *} \\
(3.674)\end{array}$ & $\begin{array}{c}0.793^{* * *} \\
(5.198)\end{array}$ \\
\hline IMF program dummy & & $\begin{array}{c}-2.135 \\
(-1.156)\end{array}$ & & $\begin{array}{l}-3.671^{*} \\
(-1.864)\end{array}$ \\
\hline HIPC dummy & & $\begin{array}{c}-4.251 \\
(-1.190)\end{array}$ & & $\begin{array}{c}11.560^{* * *} \\
(3.194)\end{array}$ \\
\hline $\begin{array}{l}\text { Observations } \\
R^{2}\end{array}$ & $\begin{array}{c}85 \\
0.669\end{array}$ & $\begin{array}{c}85 \\
0.677\end{array}$ & $\begin{array}{c}85 \\
0.763\end{array}$ & $\begin{array}{c}85 \\
0.801\end{array}$ \\
\hline
\end{tabular}




\section{Main takeaways and caveats}

While both global and country-specific factors are correlated with debt-to-GDP ratios over the sample period 1998-2016, global factors as proxied by the commodity price index and the Federal Funds rate dominate over the period 2012-16. This analysis suggests that global factors appear to have contributed more to the recent debt-to-GDP ratios increase than the country-specific factors. In particular, the strongest (negative) correlation is found for external debt-to-GDP ratio, which is likely to be the most sensitive to the global environment. The main intuition for our result is the following: The global low interest rate environment triggered higher capital inflows toward frontier LIDCs, which had the opportunity to borrow more. The opportunity to borrow at cheaper rates outweighed the savings that frontier LIDCs could get from the low interest rate environment, as it resulted in rise in the debt-to-GDP ratio along with an increase in the effective interest rate.

We also find that the regressors that are significantly correlated with debt-to-GDP ratios over the full sample are the commodity price, GDP growth, the primary fiscal balance, and the lagged debt-to-GDP ratio. Furthermore, we show that countries that received debt relief under the HIPC Initiative have lower government debt-to-GDP ratio for the sample period 1998-2011, which is the period when debt relief was carried out. By contrast, they have higher government debt-to-GDP ratios over the period 2012-16. This suggests that the countries that benefitted from HIPC debt relief started accumulating new government debt.

These results should be interpreted with caution given the small sample size due to data constraints on frontier LIDCs. In particular, the subsample 2012-16 has a relatively small number of observations, but it is the period where we witness a sharp increase in debt-toGDP ratios. More robustness tests could be conducted in the future as the IMF is revamping its efforts to improve data collection and frequency (IMF, 2018).

\section{Policy Implications}

The regression analysis that we conducted in Section IV was based on historical data and was developed to help shedding light on past debt dynamics. To draw forward-looking policy implications concerning future dynamics of the debt-to-GDP ratios, we would have liked to carry out a vector autoregression analysis where we would have studied the effects on debtto-GDP ratios of a tightening in the global financial conditions as well as in the countries' demand of funding for investment. Nevertheless, the lack of data at higher frequency than annual did not allow us to clearly identify the shocks. To enable us to draw forward-looking policy implications, we instead build a small open economy model with incomplete asset markets. This allows us to run a simulation of the future short-run dynamics of debt in response to a change in the global or country-specific conditions. In particular, we simulate a tightening in the global financial conditions (global shock) and an increase in investment (country-specific shock). ${ }^{16}$

\footnotetext{
${ }^{16}$ While the regression analyses in Section IV do not include directly investment, they include government investment (nonfinancial assets) in the primary fiscal balance, which is a component of investment. However,
}

(continued...) 


\section{A. Model}

\section{Description}

Since we believe frontier LIDCs to be small enough to be price takers, we build a model of small open economy à la Schmitt-Grohé and Uribe (2003). The economy is populated by identical agents with non-separable preferences over consumption $c$ and hours worked $h$ described by the following utility function:

$$
\sum_{t=1}^{\infty} \beta^{t} \frac{\left(c_{t}-\omega^{-1} h_{t}{ }^{\omega}\right)^{1-\sigma}-1}{1-\sigma}
$$

where $\sigma$ is the coefficient of relative risk aversion, $\omega$ is 1 plus the inverse of the Frisch elasticity of intertemporal substitution in labor supply, and $\beta$ is the discount rate. Agents can borrow from the international markets by issuing one period non-contingent bonds $d_{t}$ on which they pay an exogenous interest rate $r_{t}$ equal to the global interest rate. ${ }^{17}$ To pin down the level of debt in steady state, agents pay convex portfolio adjustment costs $\frac{\psi}{2}\left(d_{t}-d\right)^{2}$. Agents can also invest $i_{t}$ and own capital $k_{t}$. When changing the capital stock, agents face a quadratic capital adjustment cost $\frac{\phi}{2}\left(k_{t+1}-k_{t}\right)^{2}$, which is included to avoid excessive investment volatility. With capital and labor, agents produce output $y_{t}=k_{t}{ }^{\alpha} h_{t}{ }^{1-\alpha}$. The sequential budget constraint of the agents is given by:

$$
d_{t}=\left(1+r_{t-1}\right) d_{t-1}-y_{t}+c_{t}+i_{t}+\frac{\phi}{2}\left(k_{t+1}-k_{t}\right)^{2}+\frac{\psi}{2}\left(d_{t}-\mathrm{d}\right)^{2},
$$

That is, agents borrow every period to cover for the difference between expenses (debt servicing, consumption, investment, capital and portfolio adjustment costs) and output. Capital stock evolves according to:

$$
k_{t+1}=(1-\delta) k_{t}+\mu_{t} i_{t}
$$

where $\mu_{t}$ is the marginal efficiency of investment and measures how easily investment is transformed into capital (Justiniano, Primiceri, and Tambalotti, 2010). There is the following no-Ponzi condition to prevent explosive debt paths:

since in this section we do not explicitly model the government, we simulate an increase in total investment and not just public investment.

${ }^{17}$ Indeed, frontier LIDCs pay a spread on the global interest rate. Nevertheless, if we assume that this spread is inelastic to the debt stock and there is no feedback effect from changes in the global interest rate, we can make the simplifying assumption that the interest rate paid on debt is equal to the global interest rate. 


$$
\lim _{j \rightarrow \infty} E_{t} \frac{d_{t+j}}{\prod_{s=1}^{j}\left(1+r_{s}\right)} \leq 0 .
$$

Both the interest rate and the marginal efficiency of investment are exogenous and evolve according to the following autoregressive processes:

$$
\begin{aligned}
& r_{t}=\left(1-\rho_{r}\right) \mathrm{r}+\rho_{r} r_{t-1}+\varepsilon_{t}, \\
& \mu_{t}=\rho_{\mu} \mu_{t-1}+\zeta_{t},
\end{aligned}
$$

where $\varepsilon_{t}$ and $\zeta_{t}$ are i.i.d. shocks with mean zero and standard deviations $\sigma_{\varepsilon}$ and $\sigma_{\zeta}$, respectively. Agents maximize their utility (2) with respect to $\left\{c_{t}, h_{t}, y_{t}, i_{t}, k_{t+1}, d_{t}\right\}$, subject to Equations (3), (4), and (5). Given $\lambda_{t}$, the Lagrange multiplier attached to Equation (3), a competitive equilibrium is a set of processes $\left\{c_{t}, h_{t}, y_{t}, i_{t}, k_{t+1}, d_{t}, \lambda_{t}\right\}$, satisfying Equations (3), (4), (5) and the first order conditions all holding with equality, given Equations (6) and (7), and initial conditions $d_{-1}$, and $k_{0}$. For reference, in this model, the current account $C A_{t}$ and the trade balance $T B_{t}$ are defined as follows:

$$
\begin{gathered}
C A_{t}=-\left(d_{t}-d_{t-1}\right) \\
T B_{t}=y_{t}-c_{t}-i_{t}-\frac{\phi}{2}\left(k_{t+1}-k_{t}\right)^{2}-\frac{\psi}{2}\left(d_{t}-\mathrm{d}\right)^{2} .
\end{gathered}
$$

\section{Calibration}

The model is calibrated to our sample of frontier LIDCs at annual frequency over the period 2012-17. In particular, the global interest rate is calibrated to the average Federal Funds rate, while the debt-to-GDP ratio is calibrated to the cross-country average of the external debt-to-GDP ratio. The debt adjustment cost follows Uribe and Yue (2006), while the Frisch elasticity follows Schmitt-Grohé and Uribe (2003). As in Uribe and

\begin{tabular}{|lll|}
\hline \multicolumn{3}{|c|}{ Table 7. Calibration } \\
\hline Parameter & Description & Value \\
\hline$\sigma$ & risk aversion & 2 \\
$\delta$ & depreciation rate & 0.1 \\
$\alpha$ & capital share & 0.32 \\
$\omega$ & Frisch elasticity & 1.455 \\
$\phi$ & capital adjustment cost & 0.3 \\
$\psi$ & debt adjustment cost & 0.00042 \\
$r$ & global interest rate & 0.031 \\
$\beta$ & discount rate & $1 /(1+\mathrm{r})$ \\
$d / y$ & debt/GDP & 0.41 \\
$\rho_{r}$ & persistence of interest rate shock & 0.37 \\
$\rho_{\mu}$ & persistence of investment shock & 0.37 \\
\hline \multicolumn{2}{|c}{ Source: IMF staff calculations. } \\
\hline
\end{tabular}
Yue (2006), the persistence of the interest rate shock is calibrated by estimating an AR(1) process for the Federal Funds rate at an annual frequency over the period 1988 to 2017. The persistence of the marginal efficiency of investment is equalized to that of the Federal Funds rate for comparability with the interest rate shock persistence. 


\section{B. Simulations}

In this section, we simulate a tightening in the interest rate $r_{t}$ and an increase in the marginal efficiency of investment $\mu_{t}$. We calibrate the tightening of the interest rate to the Federal Open Market Committee's longer run projections, which forecast a 0.8 percentage point increase in the Federal Funds rate. In addition, we calibrate the increase in the marginal efficiency of investment to match the rise in the investment-to-GDP ratio with the crosscountry average of the WEO projections of gross capital formation up to 2024. This matching results in a simulation of a 3 -percentage point rise. ${ }^{18}$

\section{Tightening in global financing conditions}

In response to a tightening in the interest rate of 0.8 percentage points, external debt-to-GDP ratio decreases by 1.5 percentage points. At the same time, output and investment drop (Figure 9). While higher borrowing costs per se would lead to a worsening in debt sustainability prospects, the reduced supply of resources would push debt-to-GDP ratios down, which is the dominant effect. Lower borrowing leads to lower investment and, therefore, a drop in the capital stock. Lower capital makes output drop. Consumption and hours worked co-move with output, consistently with the real business cycle literature. As domestic absorption (consumption plus investment) drops more than output, the trade balance-to-GDP and the current account-to-GDP ratios improve (Figure A3, Appendix 4).

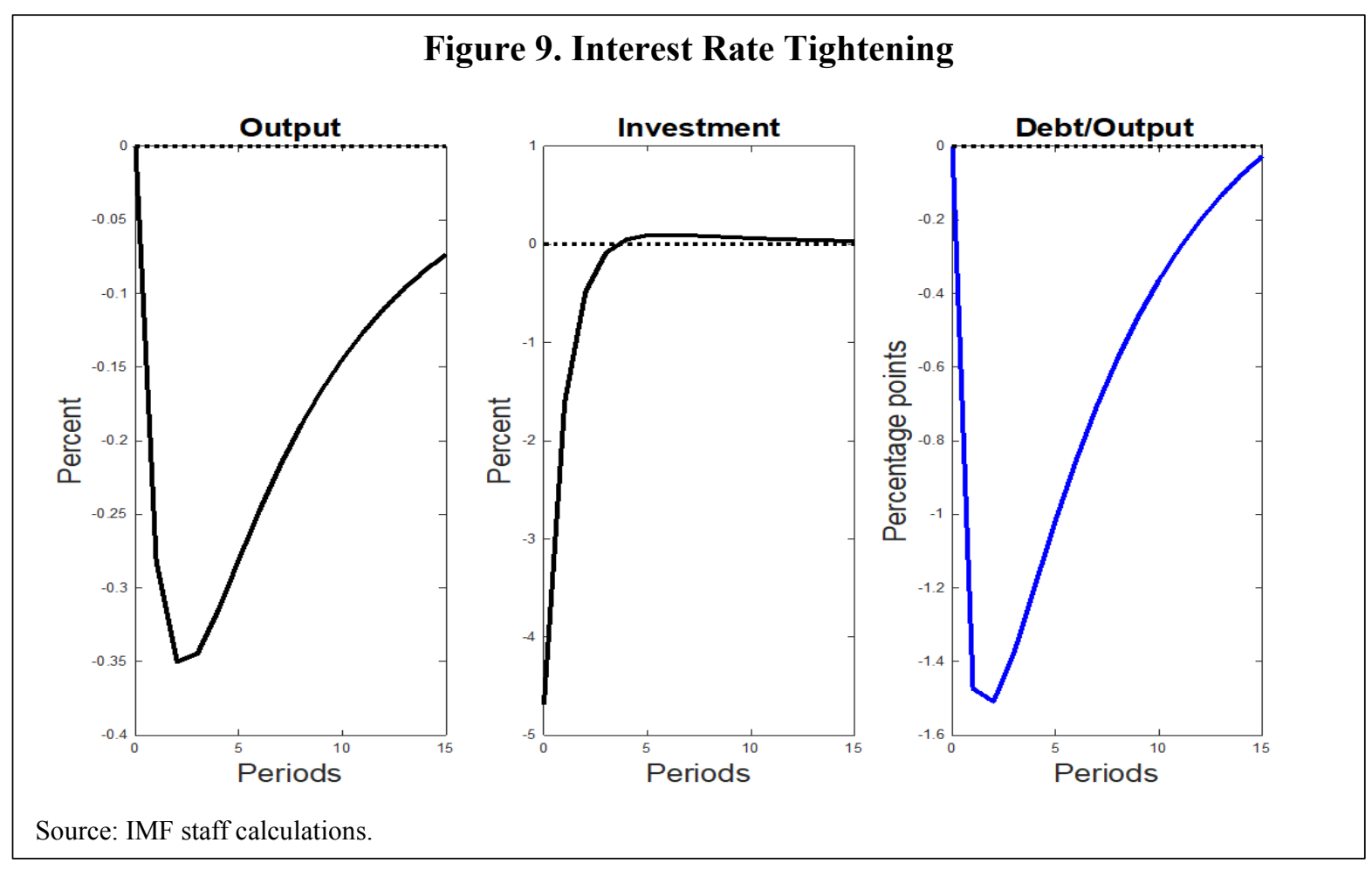

\footnotetext{
${ }^{18}$ The cross-country average of gross capital formation-to-GDP ratio rises from 27.6 percent over the period 2012-16 to 30.7 percent over the period 2017-24.
} 


\section{Increase in investment-to-GDP}

In response to an increase in investment-to-GDP by 3 percentage points triggered by a positive shock to the marginal efficiency of investment, the external debt-to-GDP ratio rises by 3 percentage points (Figure 10). At the same time, output improves. A positive shock to the marginal efficiency of investment makes the economy more productive at transforming investment into new physical capital, thus pushing agents to increase their investment. To invest more, agents borrow more, thus generating a rise in debt. Output and all subcomponents increase. The co-movement between output and consumption following a shock to the marginal efficiency of investment is obtained due to the complementarity between consumption and hours worked implied by the assumed non-separable preferences. As the debt-to-GDP ratio increases, the current account-to-GDP ratio worsens (Figure A4, Appendix 4).

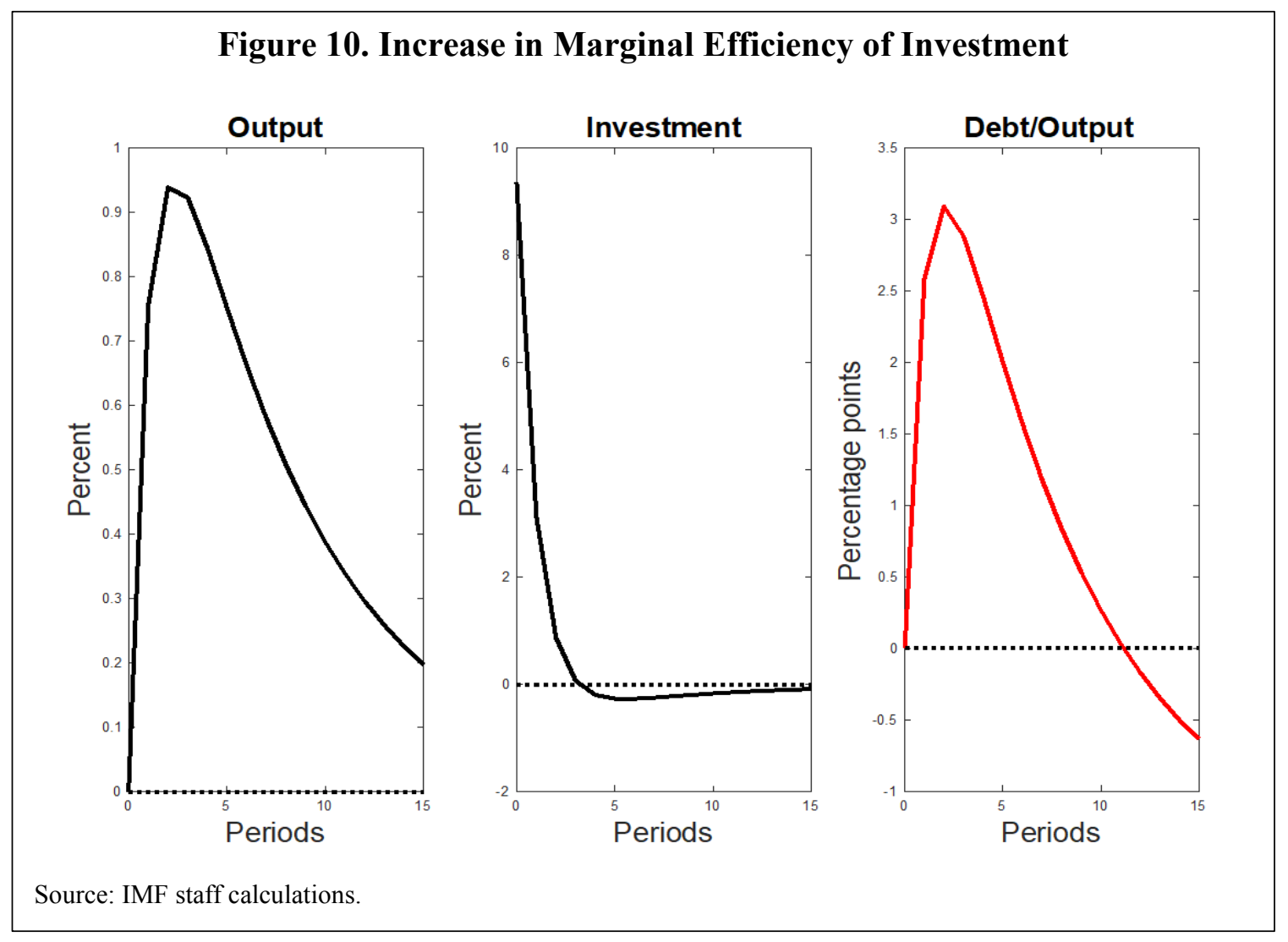

\section{Model takeaways and caveats}

The model allows us to carry out some policy simulations, given the current global and country-specific environment that frontier LIDCs are facing. Calibrating the global and the country-specific shock to medium-term projections of the Federal Funds rate and the path of investment, respectively, the reduction in the debt-to-GDP ratio associated with the expected tightening in the global interest rate (-1.5 percentage points) is not enough to offset the increase associated with the investment shock ( +3 percentage points). 
However, there are some caveats given how stylized our model is. In particular, the model features one-period external bonds, which does not allow for longer maturity debt dynamics. Moreover, as agents are subject to a non-Ponzi condition, our model focuses on sustainable debt paths. Rollover crises or ballooning debt are beyond the scope of this study. Finally, we do not explicitly model the government and, hence, we cannot directly simulate a fiscal tightening. For such an analysis, we refer the reader to Shen, Yang, and Zanna (2018), who build a detailed quantitative model to study fiscal policy in low-income countries.

\section{Conclusions}

The first part of the paper has documented the stark increase in external and government debt-to-GDP ratios that frontier LIDCs have faced over the period 2012-17. These countries have not only seen a rise in their debt-to-GDP ratios, but have also had to bear a higher interest rate on their debt. The rise in both volume and cost of debt has increased the interest rate burden that frontier LIDCs face. The stylized facts section has also shown that the composition of external debt is changing, with a higher share of debt contracted at nonconcessional terms.

The second part of the paper has aimed at determining which factors are correlated with external and government debt-to-GDP ratios, and potentially identifying reasons for the recent debt build-up. In particular, it has sought to disentangle whether country-specific or global factors dominate over the period 1998-2016 and over the two subsamples 1998-2011 and 2012-16. It has shown that both global and country-specific factors, namely commodity prices, real GDP growth, and fiscal policy, strongly correlate with debt-to-GDP ratios over the whole sample period. However, global factors as proxied by the commodity price index and the Federal Funds rate become dominant over the period 2012-16, when debt-to-GDP ratios rise sharply. Therefore, this analysis has shown that global factors appear to correlate more with frontier LIDCs' recent debt build-up compared to country-specific factors. Moreover, it has found that while the HIPC countries had lower debt-to-GDP ratios in 19982011 when the HIPC debt relief program was implemented, in 2012-16 they started building up more debt than non-HIPC countries.

The last part of the paper has drawn policy implications concerning the future debt dynamics of frontier LIDCs. In particular, we have shown that a tightening in the global interest rate would cause a reduction in debt-to-GDP ratios (global factor), as the inflows of funds toward frontier LIDCs driven by the search for yield would be reversed in the case of a tightening of the global rate. At the same time, an increase in investment (country-specific factor) would lead to an increase in debt-to-GDP ratios. Calibrating the two shocks to medium-term projections shows that the reduction in the debt-to-GDP ratio associated with the expected tightening in the global rate is not enough to offset the increase associated with the investment shock. More broadly, even if the global interest rate tightening is expected to reduce debt-to-GDP ratios in frontier LIDCs, the last part of the paper underlines the importance of domestic policies aimed at slowing down the increase.

Future research could expand the sample size, include other variables correlated with debt, and control for countries with no market access. For example, in addition to bond issuance, which is not the only type of market financing for LIDCs, loan syndications on market terms 
with foreign banks or bilateral access to neighboring country's market, and bilateral loans at floating rates could be also considered as borrowing at market terms. Also, future research could have a control group of countries with no market access and compare how their debt profiles are impacted by debt determinants. Other variables, such as remittances may play an important role for cushioning the debt burden and could be examined. Additionally, to sharpen our policy implications, future research could explicitly introduce the government as an agent in the model and study fiscal policy changes more in detail.

To conclude, this paper has made a first step toward understanding the potential drivers of the recent debt build-up that frontier LIDCs are facing. More granular data on creditors, maturities, and conditions will certainly help shed further light on the recent debt dynamics. On the policy side, while global factors seem to dominate during 2012-16, country-specific factors are still important. This implies, that while debt accumulation in these countries was by large exogenous, fiscal policy certainly played a role. Therefore, governments should create fiscal buffers by saving budgetary resources and reducing public debt in good times. ${ }^{19}$ Indeed, countries facing risk of debt distress yet still needing substantial amounts of public investment will need to reassess their fiscal strategies (IMF, 2018). At the same time, the IMF and the World Bank are launching several workstreams to address debt vulnerabilities. For example, the IMF and World Bank (2018) put the emphasis on both enhancing debt analytics and early warning systems and on strengthening capacity on debt/fiscal risk management to help countries deal with existing debt. This is particularly important given the increasing role of new lenders and their exposure in difficult debt cases (IMF, 2018).

${ }^{19}$ IMF (2015). 


\section{References}

Adler G., N. Magud, and A. Werner, 2017, "Terms-of-Trade Cycles and External Adjustment," IMF Working Paper (WP/17/29).

Anaya P. and A. Pienkowski, 2015, "What Really Drives Public Debt: A Holistic Approach," IMF Working Paper (WP/15/137).

Awan R., A. Anjum, and S. Rahim, 2014, “An Econometric Analysis of Determinants of External Debt in Pakistan," British Journal of Economics, Management \& Trade, Vol. 5 (4), pp. 382-391.

Al-Fawwaz, T., 2016, "Determinants of External Debt in Jordan: An Empirical Study," International Business Research, Vol. 9 (7), pp. 116-123.

Bittencourt M., 2015, "Determinants of Government and External Debt: Evidence from the Young Democracies of South America," Emerging Markets Finance and Trade, Vol. 51 (3), pp. 463-472.

Cashin P. and J. McDermott, 1998, "Terms of Trade Shocks and the Current Account," IMF Working Paper (WP/98/177).

Chiminya A., J. Dunne, and E. Nikolaidou, 2018, “The Determinants of External debt in Sub Saharan Africa," School of Economics Macroeconomic Discussion Paper Series.

Chinn, M. and H. Ito, 2006, "What Matters for Financial Development? Capital Controls, Institutions, and Interactions," Journal of Development Economics, Vol. 81 (1), pp. 163-192.

Dorsey T., Z. Brixiova, S. Singh, and H. Tadesse, 2008, "The Landscape of Capital Flows to Low-Income Countries”, IMF Working Paper (WP/08/51).

Eichengreen B. and P. Luengnaruemitchai, 2004, "Why Doesn't Asia Have Bigger Bond Markets?" NBER Working Paper No. 10576.

Escolano, J., 2010, “A Practical Guide to Public Debt Dynamics, Fiscal Sustainability, and Cyclical Adjustment of Budgetary Aggregates," IMF Technical Notes and Manuals No. 2010/02.

Forslund K., L. Lima, and U. Panizza, 2011, "The Determinants of the Composition of Public Debt in Developing and Emerging Market Countries," Review of Development Finance, Vol. 1, pp. 207-222.

Fratzscher, M., 2012, "Capital Flows, Push versus Pull Factors and the Global Financial Crisis," Journal of International Economics, Vol. 88, pp. 341-356. 
Guscina A., 2008, "Impact of Macroeconomic, Political, and Institutional Factors on the Structure of Government Debt in Emerging Market Countries," IMF Working Paper, (WP/08/205).

Imimole B., L. Imoughele, and M. Okhuense, 2014, "Determinants and Sustainability of External Debt in a Deregulated Economy: A Cointegration Analysis from Nigeria (19862010)," American International Journal of Contemporary Research, Vol. 4 (6), pp. 201-214.

International Monetary Fund, 2014, "Macroeconomic Developments in Low-Income Developing Countries," IMF Policy Paper.

International Monetary Fund, 2015, "Now Is the Time: Fiscal Policies for Sustainable Growth," Fiscal Monitor (April).

International Monetary Fund, 2017, "Review of the Debt Sustainability Framework in LowIncome Countries: Proposed Reforms,” IMF Policy Paper.

International Monetary Fund, 2018, "Macroeconomic Developments and Prospects in LowIncome Developing Countries -2018," IMF Policy Paper.

International Monetary Fund and the World Bank, 2018, "Debt Vulnerabilities in Emerging and Low-Income Economies."

Justiniano A., G. Primiceri, and A. Tambalotti, 2010, "Investment Shocks and Business Cycles," Journal of Monetary Economics, Volume 57 (2), pp. 132-145.

Marcelino S. and I. Hakobyan, 2014, "Does Lower Debt Buy Higher Growth? The Impact of Debt Relief Initiatives on Growth,” IMF Working Paper (WP/14/203).

Mu Y., P. Phelps, and J. Stotsky, 2013, "Bond Markets in Africa," Review of Development Finance, Vol. 3, pp. 121-135.

Pirtea M., A. Nicolescu, and P. Mota, 2013, “An Empirical Study on Public Debt's Determinants: Evidence from Romania," The Transylvanian Review of Administrative Sciences, Vol. 38, pp. 144-157.

Schmitt-Grohé S. and M. Uribe, 2003, "Closing Small Open Economy Models," Journal of International Economics, Vol. 61, pp. 163-185.

Shen W., S. Yang, and L. Zanna, 2018, “Government Spending Effects in Low-income Countries”, Journal of Development Economics, Vol. 133, pp. 201-219.

Swamy V., 2015, “Government Debt and its Macroeconomic Determinants-An Empirical Investigation,” MPRA Paper 64105, University Library of Munich, Germany. 
Tiruneh M., 2004, "An Empirical Investigation into the Determinants of External Indebtedness,” Prague Economic Papers, Vol. 3, pp. 261-277.

Uribe M. and V. Yue, 2006, "Country Spreads and Emerging Countries: Who Drives Whom?” Journal of International Economics, Vol. 69, pp. 6-36.

Woo, J., 2003, "Economic, Political, and Institutional Determinants of Public Deficits," Journal of Public Economics, Vol. 87, pp. 387-426. 


\section{Appendix 1. Literature Review of the Main Empirical Studies on Debt Determinants ${ }^{20}$}

\begin{tabular}{|c|c|c|c|c|c|}
\hline Authors & $\begin{array}{l}\text { Countries } \\
\text { and Time } \\
\text { Coverage } \\
\end{array}$ & $\begin{array}{c}\text { Dependent } \\
\text { Variable }\end{array}$ & Methodology & Independent Variables & Results \\
\hline $\begin{array}{l}\text { Awan, } \\
\text { Anjum, and } \\
\text { Werner } \\
(2014)\end{array}$ & $\begin{array}{l}\text { Pakistan } \\
1976-2010\end{array}$ & $\begin{array}{l}\text { External } \\
\text { debt (log of } \\
\text { first } \\
\text { difference } \\
\text { operator) }\end{array}$ & $\begin{array}{l}\text { Autoregressive } \\
\text { Distributed Lag } \\
\text { Model (ARDL) }\end{array}$ & $\begin{array}{l}\text { Fiscal deficit } \\
\text { Trade openness } \\
\text { Terms of trade (TOT) } \\
\text { Foreign aid } \\
\text { Nominal exchange rate }\end{array}$ & $\begin{array}{l}\text { Fiscal deficit }(+) \\
\text { Trade openness }(+) \\
\text { Nominal exchange rate }(+)\end{array}$ \\
\hline $\begin{array}{l}\text { Al-Fawwaz } \\
(2016)\end{array}$ & $\begin{array}{l}\text { Jordan } \\
\text { 1990-2014 }\end{array}$ & $\begin{array}{l}\text { External } \\
\text { debt }(\log )\end{array}$ & ARDL & $\begin{array}{l}\text { Deficit } \\
\text { Trade openness } \\
\text { TOT } \\
\text { Exchange rate } \\
\text { GDP per capita } \\
\end{array}$ & $\begin{array}{l}\text { TOT }(+) \\
\text { GDP per capita }(-)\end{array}$ \\
\hline $\begin{array}{l}\text { Bittencourt } \\
(2015)\end{array}$ & $\begin{array}{l}9 \text { South } \\
\text { America } \\
1970-2007\end{array}$ & $\begin{array}{l}\text { Government } \\
\text { and external } \\
\text { debt/GDP }\end{array}$ & $\begin{array}{l}\text { Pooled Ordinary } \\
\text { Least Squares, } \\
\text { (POLS), Fixed } \\
\text { Effects (FE), Fixed } \\
\text { Effects with } \\
\text { Instrumental } \\
\text { Variables estimator } \\
\text { (FE-IV) }\end{array}$ & $\begin{array}{l}\text { GDP growth rate } \\
\text { Trade openness } \\
\text { Inflation } \\
\text { M2 } \\
\text { Population } \\
\text { Urbanization } \\
\text { Executive constraints } \\
\text { Gov. Expenditure/GDP } \\
\text { Gini coefficient }\end{array}$ & $\begin{array}{l}\text { Depends on which debt } \\
\text { aggregate is considered. } \\
\text { Government debt: } \\
\text { GDP growth rate (-) } \\
\text { Trade openness (-) } \\
\text { M2 (+) } \\
\text { External debt: } \\
\text { GDP growth rate (-) } \\
\text { Inflation (-) }\end{array}$ \\
\hline $\begin{array}{l}\text { Chiminya, } \\
\text { Dunne, and } \\
\text { Nikolaidou } \\
(2018)\end{array}$ & $\begin{array}{l}36 \text { Sub- } \\
\text { Saharan } \\
\text { African } \\
\text { countries } \\
1975-2012\end{array}$ & $\begin{array}{l}\text { External } \\
\text { debt/GDP }\end{array}$ & $\begin{array}{l}\text { OLS, FE, } \\
\text { Generalized Method } \\
\text { of Moments (GMM) }\end{array}$ & $\begin{array}{l}\text { GDP } \\
\text { GDP growth rate } \\
\text { Trade openness } \\
\text { Inflation } \\
\text { Real rate of interest } \\
\text { Gross capital formation } \\
\text { Reserves to external debt } \\
\text { HIPC initiative dummy } \\
\text { Population } \\
\text { Executive constraints } \\
\text { Regime type } \\
\text { Electoral competitiveness } \\
\text { Parliamentary or } \\
\text { presidential }\end{array}$ & $\begin{array}{l}\text { GDP growth rate }(-) \\
\text { Trade openness }(-) \\
\text { Real rate of interest }(+) \\
\text { Gross capital formation }(+) \\
\text { HIPC initiative dummy }(-) \\
\text { Executive constraints }(-) \\
\text { Regime type }(+) \\
\text { Electoral competitiveness }(-) \\
\text { Parliamentary or presidential } \\
(+)\end{array}$ \\
\hline $\begin{array}{l}\text { Eichengreen } \\
\text { and } \\
\text { Luengna- } \\
\text { ruemitchai } \\
\text { (2004) }\end{array}$ & $\begin{array}{l}\text { Advanced } \\
\text { economies } \\
\text { 1990-2001 }\end{array}$ & $\begin{array}{l}\text { Domestic } \\
\text { currency } \\
\text { bonds }\end{array}$ & $\begin{array}{l}\text { Panel Generalized } \\
\text { Least Squares } \\
\text { (GLS) }\end{array}$ & $\begin{array}{l}\text { GDP } \\
\text { Exports to GDP } \\
\text { English legal origins } \\
\text { dummy } \\
\text { Distance from equator } \\
\text { Investment profile } \\
\text { Law and order } \\
\text { GDP per capita } \\
\text { Corruption } \\
\text { Accounting standards } \\
\text { Domestic credit provided } \\
\text { by banking sector } \\
\text { Concentration in banking } \\
\text { sector } \\
\text { Bureaucracy quality } \\
\text { Standard dev. of interbank } \\
\text { interest rates }\end{array}$ & $\begin{array}{l}\text { GDP }(+) \\
\text { Exports to GDP }(+) \\
\text { English legal origins dummy } \\
(-) \\
\text { Distance from equator }(+) \\
\text { Investment profile }(-) \\
\text { Accounting standards }(+) \\
\text { Dom. credit provided by } \\
\text { banking sector }(+) \\
\text { Concentration in banking } \\
\text { sector }(-) \\
\text { Standard dev. of interbank } \\
\text { interest rates }(+) \\
\text { Interest rate spread }(-) \\
\text { IMF capital controls dummy } \\
(+)\end{array}$ \\
\hline
\end{tabular}

${ }^{20}(+)$ and (-) refer to the sign of the correlation (when significantly different from zero) between the indicated variable and the dependent variable. 


\begin{tabular}{|c|c|c|c|c|c|}
\hline Authors & $\begin{array}{l}\text { Countries } \\
\text { and Time } \\
\text { Coverage }\end{array}$ & $\begin{array}{l}\text { Dependent } \\
\text { Variable }\end{array}$ & Methodology & Independent Variables & Results \\
\hline & & & & $\begin{array}{l}\text { Interest rate spread } \\
\text { Standard dev. of change in } \\
\text { log of nominal exchange } \\
\text { rates } \\
\text { IMF capital controls } \\
\text { dummy }\end{array}$ & \\
\hline $\begin{array}{l}\text { Forslund, } \\
\text { Lima, and } \\
\text { Panizza } \\
(2011)\end{array}$ & $\begin{array}{l}104 \\
\text { developing } \\
\text { countries } \\
1990-2007\end{array}$ & $\begin{array}{l}\text { Domestic } \\
\text { public } \\
\text { debt/public } \\
\text { debt }\end{array}$ & $\begin{array}{l}\text { FE, Random Effects } \\
\text { (RE) }\end{array}$ & $\begin{array}{l}\text { Inflation } \\
\text { Current account to GDP } \\
\text { Banking crisis dummy } \\
\text { Default dummy } \\
\text { M2 to GDP } \\
\text { GDP } \\
\text { GDP per capita } \\
\text { Debt to GDP } \\
\text { Change in real exchange } \\
\text { rate } \\
\text { Openness (trade and fin.) } \\
\text { Corruption } \\
\text { Debt contraction dummy } \\
\text { Debt explosion dummy } \\
\text { Capital controls } \\
\text { Government balance to } \\
\text { GDP } \\
\text { Exchange rate } \\
\text { misalignment }\end{array}$ & $\begin{array}{l}\text { Depends on group of } \\
\text { countries. } \\
\text { Low-income countries: } \\
\text { Banking crisis (-) } \\
\text { M2 to GDP }(+) \\
\text { GDP per capita }(+) \\
\text { Change in real exchange rate } \\
(-) \\
\text { Openness (trade and fin.) }(+) \\
\text { Middle income countries: } \\
\text { GDP (+) } \\
\text { Debt to GDP (+) } \\
\text { Change in real exchange rate } \\
(-) \\
\text { Debt explosion dummy }(+)\end{array}$ \\
\hline $\begin{array}{l}\text { Guscina } \\
(2008)\end{array}$ & $\begin{array}{l}19 \\
\text { emerging } \\
\text { countries } \\
1980-2005\end{array}$ & $\begin{array}{l}\text { Public debt } \\
\text { shares } \\
\text { according to } \\
\text { residency of } \\
\text { lender, } \\
\text { maturity, } \\
\text { and currency }\end{array}$ & OLS, FE & $\begin{array}{l}\text { M2 } \\
\text { Stock market } \\
\text { capitalization/GDP } \\
\text { Private credit to banks to } \\
\text { GDP } \\
\text { Private savings to GDP } \\
\text { Trade to GDP } \\
\text { Exchange rate stability } \\
\text { index } \\
\text { Inflation } \\
\text { Real exchange rate } \\
\text { volatility } \\
\text { Political stability } \\
\text { Quality of bureaucracy }\end{array}$ & $\begin{array}{l}\text { Depends on which debt } \\
\text { aggregate is considered. } \\
\text { Domestic over total debt: } \\
\text { Private credit to banks to GDP } \\
(-) \\
\text { Private savings to GDP (+) } \\
\text { Inflation (+) } \\
\text { Political stability (+) } \\
\text { Traded debt over domestic } \\
\text { debt: } \\
\text { Private savings to GDP (+) } \\
\text { Domestic long-term fixed rate } \\
\text { debt over domestic debt: } \\
\text { M2 to GDP (+) } \\
\text { Inflation (-) } \\
\text { Private savings to GDP (-) } \\
\text { Stock market capitalization to } \\
\text { GDP (-) } \\
\text { Quality of bureaucracy (+) }\end{array}$ \\
\hline $\begin{array}{l}\text { Imimole, } \\
\text { Imoughele, } \\
\text { and } \\
\text { Okhuense } \\
(2014)\end{array}$ & $\begin{array}{l}\text { Nigeria } \\
1986-2010\end{array}$ & $\begin{array}{l}\text { External } \\
\text { debt/GDP }\end{array}$ & $\begin{array}{l}\text { Error Correction } \\
\text { Model (ECM) }\end{array}$ & $\begin{array}{l}\text { TOT } \\
\text { External debt } \\
\text { service/Export } \\
\text { Openness } \\
\text { Budget deficit/GDP } \\
\text { FDI } \\
\text { GDP } \\
\text { Exchange rate } \\
\text { (domestic/1\$) }\end{array}$ & $\begin{array}{l}\text { External debt service/Export } \\
(+) \\
\text { GDP }(-) \\
\text { Exchange rate }(+)\end{array}$ \\
\hline
\end{tabular}

\section{CInternational Monetary Fund. Not for Redistribution}




\begin{tabular}{|c|c|c|c|c|c|}
\hline Authors & $\begin{array}{l}\text { Countries } \\
\text { and Time } \\
\text { Coverage }\end{array}$ & $\begin{array}{l}\text { Dependent } \\
\text { Variable }\end{array}$ & Methodology & Independent Variables & Results \\
\hline $\begin{array}{l}\text { Mu, Phelps, } \\
\text { and Stotsky } \\
(2013)\end{array}$ & $\begin{array}{l}\text { Sub- } \\
\text { Saharan } \\
\text { African } \\
\text { countries } \\
1980-2010\end{array}$ & $\begin{array}{l}\text { Bond (gov. } \\
\text { and } \\
\text { corporate) } \\
\text { market } \\
\text { capitalizatio } \\
\mathrm{n} \text { in local } \\
\text { currency }\end{array}$ & $\begin{array}{l}\text { POLS, FE, RE, } \\
\text { GMM }\end{array}$ & $\begin{array}{l}\text { Economic size } \\
\text { Trade openness } \\
\text { GDP per capita } \\
\text { Banking sector size } \\
\text { Bank lending spread } \\
\text { Interest rate variability } \\
\text { Standard dev. of change in } \\
\text { log of nominal exchange } \\
\text { rate } \\
\text { Capital account openness } \\
\text { Fiscal balance } \\
\text { Economic development } \\
\text { Law and order } \\
\text { Corruption } \\
\text { Investment profile } \\
\text { Bureaucracy } \\
\text { Composite risk } \\
\text { Legal system is English } \\
\text { Country size in terms of } \\
\text { land area }\end{array}$ & $\begin{array}{l}\text { Trade openness (-) } \\
\text { Bank lending spread (-) } \\
\text { Exchange rate variability (-) } \\
\text { Capital account openness (-) } \\
\text { Fiscal balance (-) } \\
\text { Law and order (+) } \\
\text { Country size in terms of land } \\
\text { area (-) }\end{array}$ \\
\hline $\begin{array}{l}\text { Pirtea, } \\
\text { Nocolescu, } \\
\text { and Mota } \\
(2013)\end{array}$ & $\begin{array}{l}\text { Romania } \\
\text { Q12000- } \\
\text { Q22011 }\end{array}$ & $\begin{array}{l}\text { First } \\
\text { difference } \\
\text { operator } \\
\text { (public } \\
\text { debt/GDP) }\end{array}$ & OLS & $\begin{array}{l}\text { Primary surplus } \\
\text { Real interest rate } \\
\text { Real GDP growth } \\
\text { Nominal exchange rate } \\
\text { Trade openness } \\
\text { FDI } \\
\text { Election dummy } \\
\text { Temporary gov. } \\
\text { expenditure } \\
\text { Cyclical state of the } \\
\text { economy }\end{array}$ & $\begin{array}{l}\text { Real interest rate }(+) \\
\text { GDP growth }(-) \\
\text { Nominal exchange rate }(+) \\
\text { Primary surplus }(-)\end{array}$ \\
\hline $\begin{array}{l}\text { Swamy } \\
(2015)\end{array}$ & $\begin{array}{l}252 \\
\text { countries } \\
1980-2009\end{array}$ & Public debt & GMM & $\begin{array}{l}\text { Real GDP growth } \\
\text { Final consumption } \\
\text { FDI } \\
\text { Gov. expenditure } \\
\text { Inflation } \\
\text { Trade openness } \\
\text { Gross fixed capital } \\
\text { formation } \\
\text { Real interest rate } \\
\text { Age dependency ratio } \\
\text { Population growth } \\
\text { Unemployed labor force }\end{array}$ & $\begin{array}{l}\text { Real GDP growth (-) } \\
\text { Final consumption (+) } \\
\text { FDI (-) } \\
\text { Gov. expenditure (-) } \\
\text { Trade openness }(+) \\
\text { Gross fixed capital formation } \\
(+) \\
\text { Population growth (-) }\end{array}$ \\
\hline $\begin{array}{l}\text { Tiruneh } \\
(2004)\end{array}$ & $\begin{array}{l}60 \\
\text { developing } \\
\text { countries } \\
1992-98\end{array}$ & $\begin{array}{l}\text { External } \\
\text { debt/GDP }\end{array}$ & RE, FE & $\begin{array}{l}\text { Standard dev. of exports } \\
\text { Tot. debt service to export } \\
\text { Capital flight to export } \\
\text { Perc. Change in TOT } \\
\text { Import to GDP } \\
\text { GDP } \\
\text { GDP growth } \\
\text { Population } \\
\text { HIPC initiative dummy }\end{array}$ & $\begin{array}{l}\text { Capital flight }(+) \\
\text { Import to GDP }(+) \\
\text { Tot debt service to export }(+) \\
\text { GDP (-) } \\
\text { GDP growth (-) }\end{array}$ \\
\hline
\end{tabular}




\section{Appendix 2. Data Sources and Description}

\begin{tabular}{|c|c|c|c|}
\hline Variables & Definition & Sources & Time span \\
\hline Broad money & $\begin{array}{l}\text { Broad money as defined by the national authorities. Broad } \\
\text { money typically comprises the sum of currency outside } \\
\text { depository corporations, transferable and nontransferable } \\
\text { deposits held by residents other than those of the central } \\
\text { government, and in some countries also securities other than } \\
\text { shares issued by depository corporations that are very liquid. }\end{array}$ & $\begin{array}{l}\text { IMF World } \\
\text { Economic Outlook } \\
\text { database }\end{array}$ & 1998-2017 \\
\hline $\begin{array}{l}\text { Commodity exporter } \\
\text { dummy }\end{array}$ & $\begin{array}{l}\text { Equal one if commodity exporter. Countries are defined as } \\
\text { commodity exporters when at least } 50 \text { percent of their export } \\
\text { earnings come from fuels and primary commodities. }\end{array}$ & $\begin{array}{l}\text { IMF World } \\
\text { Economic Outlook } \\
\text { database }\end{array}$ & 1998-2017 \\
\hline Commodity price index & $\begin{array}{l}\text { Commodity industrial inputs price index: a combination of } \\
\text { agricultural materials and metal price indices. } \\
\text { Crude oil index: a simple average of Dated Brent, West } \\
\text { Texas Intermediate, and the Dubai Fateh. }\end{array}$ & $\begin{array}{l}\text { IMF World } \\
\text { Economic Outlook } \\
\text { database }\end{array}$ & $1998-2017$ \\
\hline $\begin{array}{l}\text { Concessional external } \\
\text { debt }\end{array}$ & $\begin{array}{l}\text { Defined by the World Bank, International Debt Statistics as } \\
\text { loans with an original grant element of } 25 \text { percent or more. }\end{array}$ & $\begin{array}{l}\text { World Bank, World } \\
\text { Development } \\
\text { Indicators database }\end{array}$ & $2000-16$ \\
\hline Corruption & $\begin{array}{l}\text { Higher values of corruption index mean better institutional } \\
\text { quality. }\end{array}$ & $\begin{array}{l}\text { International Country } \\
\text { Risk Guide index }\end{array}$ & 1998-2017 \\
\hline Current account balance & $\begin{array}{l}\text { Includes: a) goods and services account, b) primary income } \\
\text { account, and c) secondary income account. } \\
\text { a) Goods and services account shows transactions in items } \\
\text { that are outcomes of production activities between residents } \\
\text { and nonresidents. } \\
\text { b) Primary income account shows income flows between } \\
\text { residents and nonresidents. } \\
\text { c) Secondary income account shows current transfers } \\
\text { between residents and nonresidents. }\end{array}$ & $\begin{array}{l}\text { IMF World } \\
\text { Economic Outlook } \\
\text { database }\end{array}$ & $1998-2017$ \\
\hline $\begin{array}{l}\text { Capital account } \\
\text { openness }\end{array}$ & $\begin{array}{l}\text { Chinn-Ito index (KAOPEN) is measuring a country's degree } \\
\text { of capital account openness. The index was initially } \\
\text { introduced in Chinn and Ito (Journal of Development } \\
\text { Economics, 2006). KAOPEN is based on the binary dummy } \\
\text { variables that codify the tabulation of restrictions on cross- } \\
\text { border financial transactions reported in the IMF's Annual } \\
\text { Report on Exchange Arrangements and Exchange } \\
\text { Restrictions (AREAER). }\end{array}$ & $\begin{array}{l}\text { http://web.pdx.edu/ i } \\
\text { to/Chinn- } \\
\text { Ito_website.htm }\end{array}$ & $1998-2016$ \\
\hline Effective interest rate & Ratio of interest service at time $t$ over debt level at t- 1 . & Authors' calculations & 1998-2017 \\
\hline Exchange rate & National currency units per U.S. dollar, period average. & $\begin{array}{l}\text { IMF World } \\
\text { Economic Outlook } \\
\text { database }\end{array}$ & $1998-2017$ \\
\hline Exports & Exports of goods and services, current prices. & $\begin{array}{l}\text { IMF World } \\
\text { Economic Outlook } \\
\text { database }\end{array}$ & 1998-2017 \\
\hline
\end{tabular}




\begin{tabular}{|c|c|c|c|}
\hline Variables & Definition & Sources & Time span \\
\hline External debt & $\begin{array}{l}\text { Debt is defined as external on the criterion of residency. } \\
\text { Namely, gross external debt, at any given time, is the } \\
\text { outstanding amount of those actual current, and not } \\
\text { contingent, liabilities that require payment(s) of principal } \\
\text { and/or interest by the debtor at some point(s) in the future and } \\
\text { that are owed to nonresidents by residents of an economy. } \\
\text { By type of debtor: Official debt is debt owed by the resident } \\
\text { general government and monetary authorities to all foreign } \\
\text { (non-resident) sectors, bank debt is debt owed by resident } \\
\text { banks to all foreign (non-resident) sectors, while other private } \\
\text { debt is owed by non-bank financial corporations, } \\
\text { nonfinancial corporations, and households and nonprofit } \\
\text { institutions serving the household subsector. } \\
\text { By maturity: Long-term debt is defined as debt with an } \\
\text { original maturity of more than one year or with no stated } \\
\text { maturity. Short-term debt is with an original maturity of less } \\
\text { than or equal to one year. }\end{array}$ & $\begin{array}{l}\text { IMF World } \\
\text { Economic Outlook } \\
\text { database }\end{array}$ & $1998-2017$ \\
\hline $\begin{array}{l}\text { External government } \\
\text { debt }\end{array}$ & $\begin{array}{l}\text { Debt owed by the resident general government and monetary } \\
\text { authorities to all foreign (non-resident) sectors. }\end{array}$ & $\begin{array}{l}\text { IMF World } \\
\text { Economic Outlook } \\
\text { database }\end{array}$ & 1998-2017 \\
\hline FDI inflows & $\begin{array}{l}\text { Direct investment is a category of cross-border investment } \\
\text { associated with a resident in one economy having control or a } \\
\text { significant degree of influence on the management of an } \\
\text { enterprise that is resident in another economy. }\end{array}$ & $\begin{array}{l}\text { IMF World } \\
\text { Economic Outlook } \\
\text { database }\end{array}$ & $1998-2017$ \\
\hline Federal Funds rate & Effective Federal Funds rate. & FRED St. Louis Fed & $1998-2017$ \\
\hline Fiscal balance & $\begin{array}{l}\text { Overall fiscal balance: difference between revenues and } \\
\text { grants, and expenditure and net lending. } \\
\text { Primary fiscal balance: excludes interest payments from } \\
\text { expenditure. }\end{array}$ & $\begin{array}{l}\text { IMF World } \\
\text { Economic Outlook } \\
\text { database }\end{array}$ & $1998-2017$ \\
\hline Government debt & $\begin{array}{l}\text { General government gross debt consists of all liabilities that } \\
\text { require payment or payments of interest and/or principal by } \\
\text { the debtor to the creditor at a date or dates in the future. This } \\
\text { includes debt liabilities in the form of SDRs, currency and } \\
\text { deposits, debt securities, loans, insurance, pensions and } \\
\text { standardized guarantee schemes, and other accounts payable. }\end{array}$ & $\begin{array}{l}\text { IMF World } \\
\text { Economic Outlook } \\
\text { database }\end{array}$ & $1998-2017$ \\
\hline $\begin{array}{l}\text { Government } \\
\text { expenditure }\end{array}$ & $\begin{array}{l}\text { Includes: a) total expense, and b) the net acquisition of } \\
\text { nonfinancial assets. } \\
\text { a) Total expense: Consists of compensation of employees, } \\
\text { goods and services used by government, consumption of } \\
\text { fixed capital ("depreciation"), interest, subsidies, grants } \\
\text { paid/payable, social benefits, and other expense. } \\
\text { b) Net acquisition of nonfinancial assets: The acquisitions } \\
\text { minus the disposals of nonfinancial assets minus the } \\
\text { consumption of fixed capital }\end{array}$ & $\begin{array}{l}\text { IMF World } \\
\text { Economic Outlook } \\
\text { database }\end{array}$ & $1998-2017$ \\
\hline Government revenue & $\begin{array}{l}\text { Consists of taxes, social contributions, grants receivable, and } \\
\text { other revenue (this includes property income, proceeds from } \\
\text { sales of goods and services; and fines, penalties, and forfeits; } \\
\text { voluntary transfers other than grants, and miscellaneous other } \\
\text { revenues). }\end{array}$ & $\begin{array}{l}\text { IMF World } \\
\text { Economic Outlook } \\
\text { database }\end{array}$ & $1998-2017$ \\
\hline
\end{tabular}




\begin{tabular}{|c|c|c|c|}
\hline Variables & Definition & Sources & Time span \\
\hline HIPC dummy & $\begin{array}{l}\text { Equal to zero before the completion date of the HIPC } \\
\text { Initiative and to one for the post-completion period. } \\
\text { The HIPC Initiative was launched in } 1996 \text { by the IMF and } \\
\text { World Bank, with the aim of ensuring that no poor country } \\
\text { faces a debt burden it cannot manage. Since then, the } \\
\text { international financial community, including multilateral } \\
\text { organizations and governments, have worked together to } \\
\text { reduce to sustainable levels the external debt burdens of the } \\
\text { most heavily indebted poor countries. In 1999, a } \\
\text { comprehensive review of the Initiative allowed the Fund to } \\
\text { provide faster, deeper, and broader debt relief and } \\
\text { strengthened the links between debt relief, poverty reduction, } \\
\text { and social policies. }\end{array}$ & Authors' calculations & $1998-2017$ \\
\hline IMF program dummy & $\begin{array}{l}\text { Equal to one in the years when a country is engaged in an } \\
\text { IMF program (financial or non-financial) and zero otherwise. } \\
\text { The IMF programs that we consider in this paper include } \\
\text { arrangements using either existing or previous IMF facilities: } \\
\text { (i) the Extended Credit Facility, Standby Credit Facility, } \\
\text { Rapid Credit Facility, Policy Support Instrument, Stand-By } \\
\text { Arrangement, Extended Fund Facility, and Staff-Monitored } \\
\text { Program are existing IMF facilities or instruments; and (ii) } \\
\text { the Exogenous Shocks Facility, Emergency Post-Conflict } \\
\text { Assistance, and Emergency Natural Disaster Assistance are } \\
\text { previous facilities that no longer exist. }\end{array}$ & Authors' calculations & $1998-2017$ \\
\hline Imports & Imports of goods and services, constant prices. & $\begin{array}{l}\text { IMF World } \\
\text { Economic Outlook } \\
\text { database }\end{array}$ & $1998-2017$ \\
\hline Interest payments & $\begin{array}{l}\text { General government interest payments: Expense that the } \\
\text { general government unit (the debtor) incurs for the use of the } \\
\text { principal outstanding, which is the economic value that has } \\
\text { been provided by the creditor in the form of deposits, debt } \\
\text { securities, loans, and accounts payable. } \\
\text { Interest payment on external debt: Periodic payments of } \\
\text { interest costs paid by borrower during the year current. }\end{array}$ & $\begin{array}{l}\text { IMF World } \\
\text { Economic Outlook } \\
\text { database }\end{array}$ & $1998-2017$ \\
\hline Political risk & $\begin{array}{l}\text { Higher values of the political risk index mean less political } \\
\text { instability. }\end{array}$ & $\begin{array}{l}\text { International Country } \\
\text { Risk Guide index }\end{array}$ & $1998-2017$ \\
\hline Portfolio inflows & $\begin{array}{l}\text { Cross-border transactions and positions involving debt, } \\
\text { equity and investment fund shares, other than those included } \\
\text { in the categories of direct investment and reserve assets. }\end{array}$ & $\begin{array}{l}\text { IMF World } \\
\text { Economic Outlook } \\
\text { database }\end{array}$ & $1998-2017$ \\
\hline Real GDP growth & $\begin{array}{l}\text { Gross domestic product, constant prices, National Currency, } \\
\text { percent change. }\end{array}$ & $\begin{array}{l}\text { IMF World } \\
\text { Economic Outlook } \\
\text { database }\end{array}$ & $1998-2017$ \\
\hline Terms of trade & Terms of trade, total, US Dollars, percent change. & $\begin{array}{l}\text { IMF World } \\
\text { Economic Outlook } \\
\text { database }\end{array}$ & $1998-2017$ \\
\hline VIX & $\begin{array}{l}\text { CBOE Volatility index (VIX): measure of constant, 30-day } \\
\text { expected volatility of the U.S. stock market, derived from } \\
\text { real-time, mid-quote prices of S\&P 500® Index (SPXSM) } \\
\text { call and put options. }\end{array}$ & FRED St. Louis Fed & $1998-2017$ \\
\hline
\end{tabular}




\section{Appendix 3. Debt-to-GDP Ratios: Descriptive Statistics}

Figure A3.1 and Table A3.1 show that the mean is above the median and the standard deviation is increasing again from 2012 to 2017 . This implies that the dispersion of debt-toGDP ratios is increasing across countries and it is mainly driven by the countries having a debt-to-GDP ratio above the sample median.

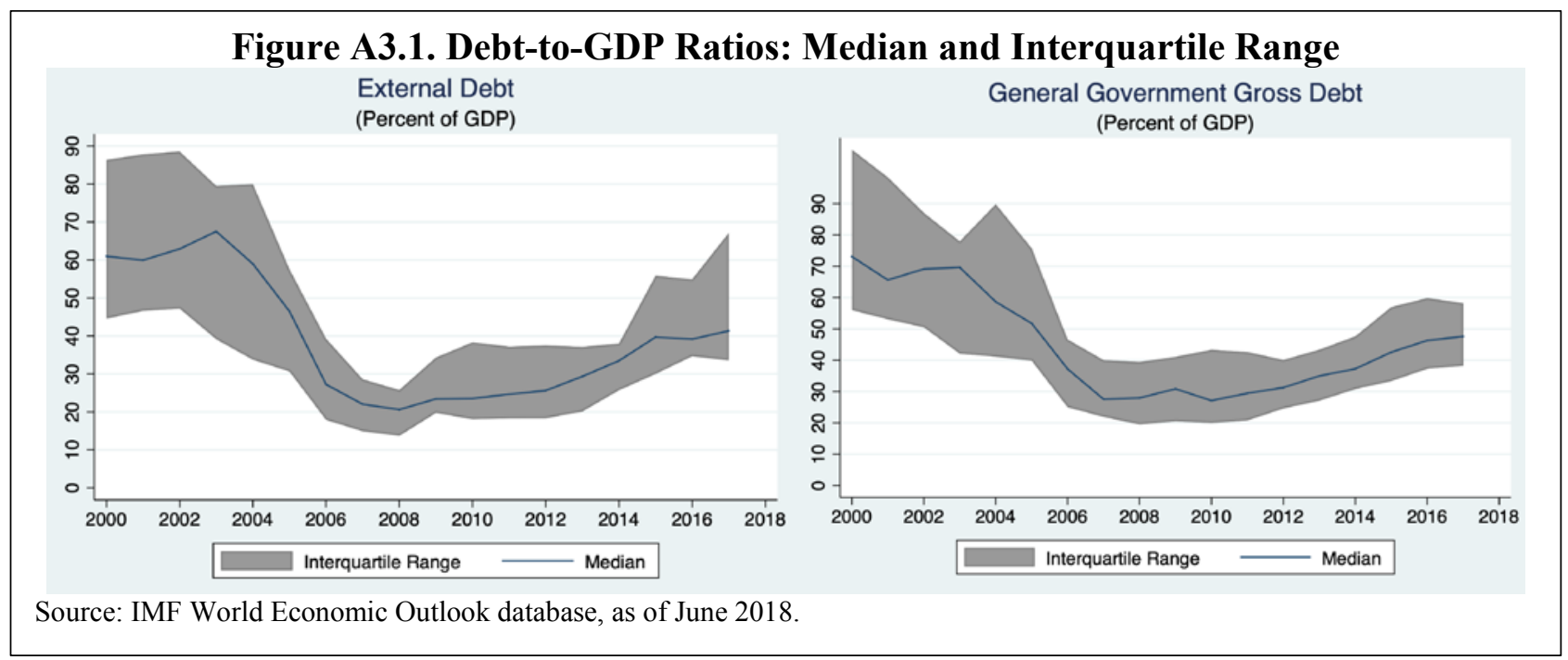

\begin{tabular}{|lcccccc|}
\hline \multicolumn{8}{|c|}{ Table A3.1. Debt-to-GDP Ratios: Additional Descriptive Statistics } \\
\hline $\begin{array}{l}\text { Debt } \\
\text { (percent of GDP) }\end{array}$ & Year & Mean & Std. Deviation & Median & 25th Percentile & 75 th Percentile \\
\hline External & 2000 & 80.59 & 51.68 & 60.98 & 44.57 & 86.38 \\
& 2012 & 30.35 & 18.82 & 25.61 & 18.31 & 37.46 \\
& 2017 & 49.35 & 31.18 & 41.32 & 33.53 & 67.12 \\
& 2000 & 91.56 & 56.34 & 73.10 & 56.01 & 40.09 \\
Government & 2012 & 31.65 & 10.91 & 31.27 & 24.60 & 58.23 \\
\hline
\end{tabular}




\section{Appendix 4. Additional Impulse Response Functions to Shocks}

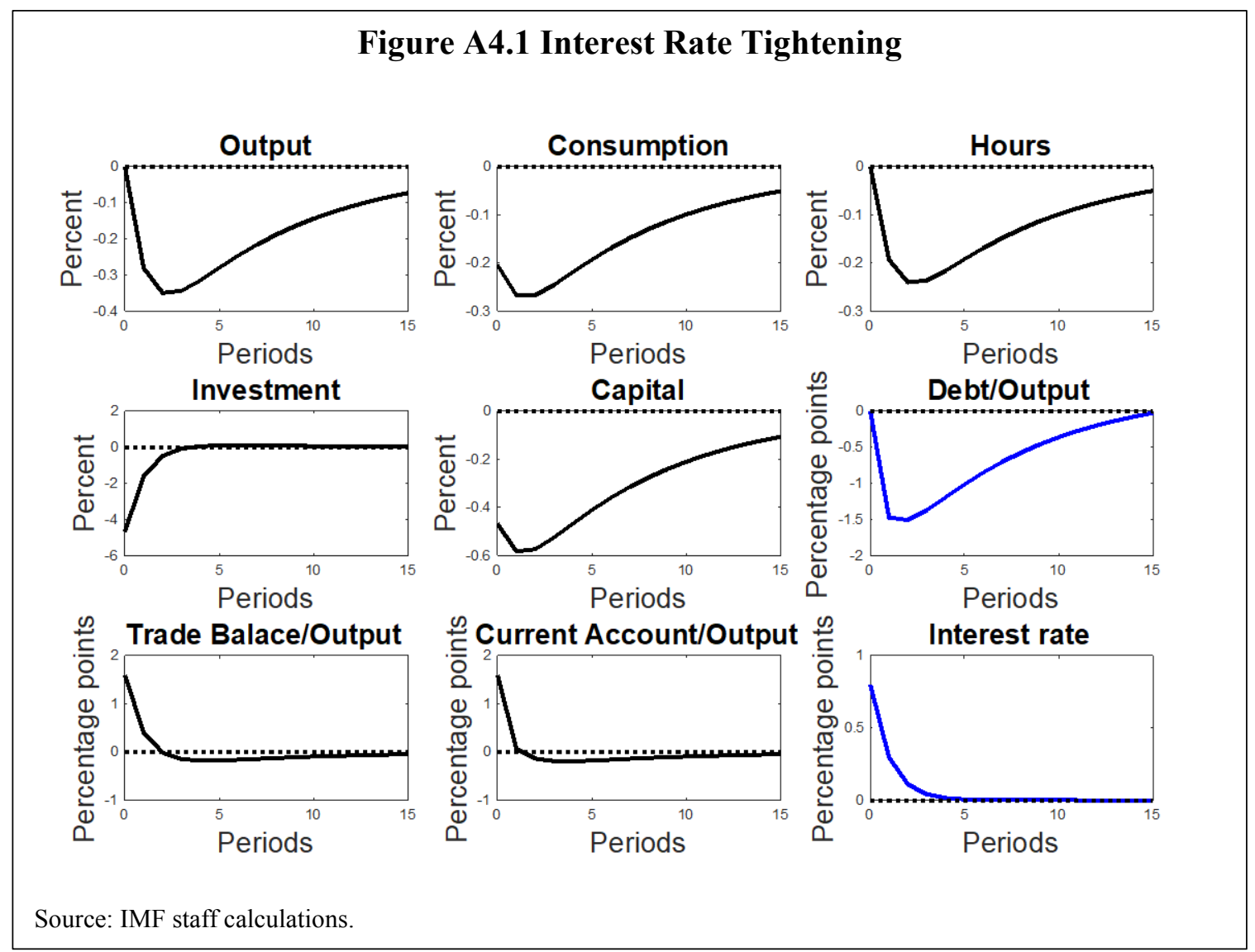




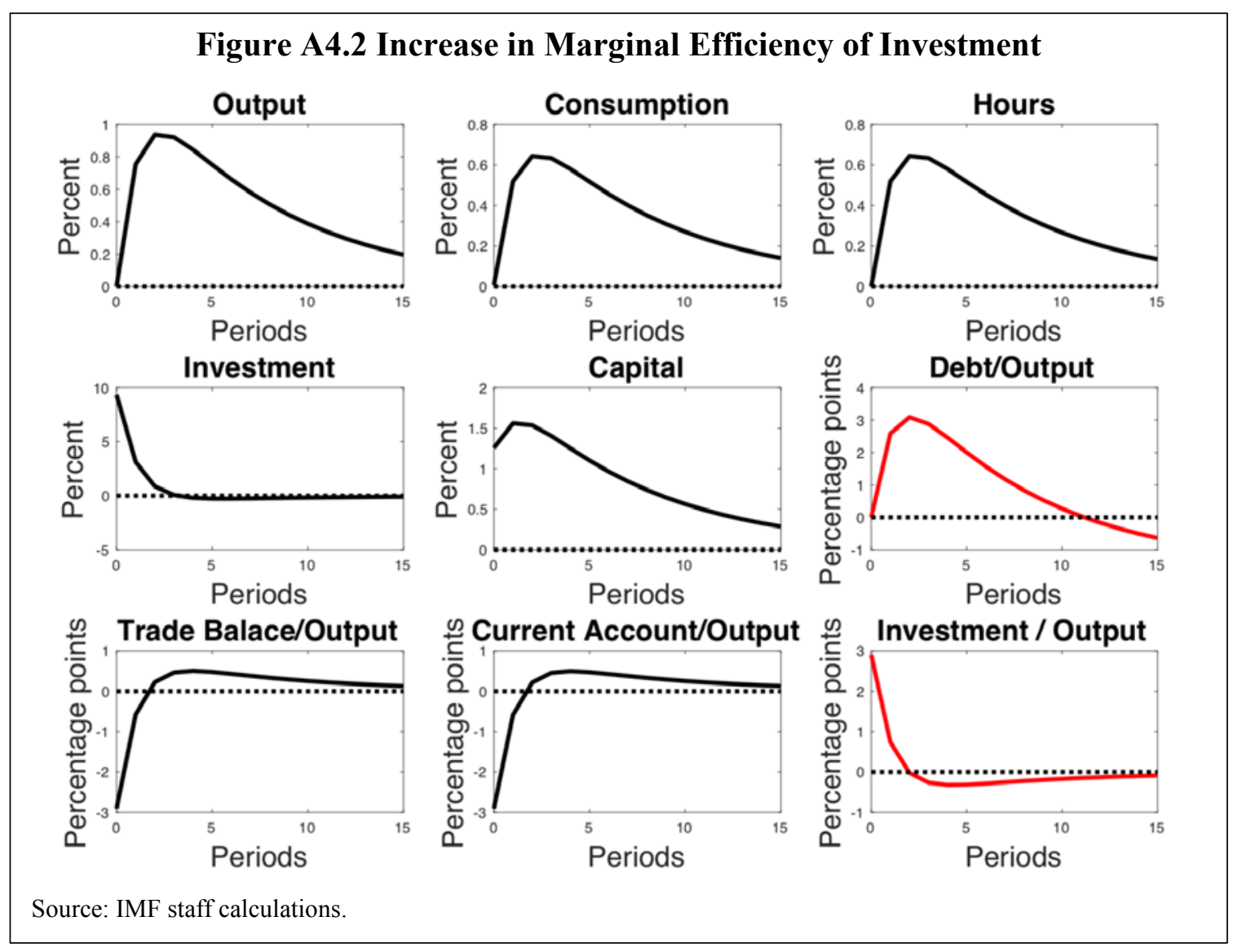

CInternational Monetary Fund. Not for Redistribution 